\title{
Extraintestinal Pathogenic Escherichia coli: Virulence Factors and Antibiotic Resistance
}

\author{
Valerio M. Sora *(D), Gabriele Meroni (D), Piera A. Martino (D), Alessio Soggiu (D), Luigi Bonizzi \\ and Alfonso Zecconi (D)
}

Citation: Sora, V.M.; Meroni, G.;

Martino, P.A.; Soggiu, A.; Bonizzi, L.; Zecconi, A. Extraintestinal Pathogenic Escherichia coli: Virulence Factors and Antibiotic Resistance. Pathogens 2021, 10, 1355. https://doi.org/10.3390/ pathogens10111355

Academic Editor:

María-Teresa Pérez-Gracia

Received: 6 September 2021

Accepted: 18 October 2021

Published: 20 October 2021

Publisher's Note: MDPI stays neutral with regard to jurisdictional claims in published maps and institutional affiliations.

Copyright: (c) 2021 by the authors. Licensee MDPI, Basel, Switzerland. This article is an open access article distributed under the terms and conditions of the Creative Commons Attribution (CC BY) license (https:// creativecommons.org/licenses/by/ $4.0 /)$.
Surgical and Dental Sciences-One Health Unit, Department of Biomedical, School of Medicine, University of Milan, Via Pascal 36, 20133 Milan, Italy; gabriele.meroni@unimi.it (G.M.); piera.martino@unimi.it (P.A.M.); alessio.soggiu@unimi.it (A.S.); luigi.bonizzi@unimi.it (L.B.); alfonso.zecconi@unimi.it (A.Z.)

* Correspondence: valerio.sora@unimi.it; Tel.: +39-33-5812-0996
Abstract: The One Health approach emphasizes the importance of antimicrobial resistance (AMR) as a major concern both in public health and in food animal production systems. As a general classification, E. coli can be distinguished based on the ability to cause infection of the gastrointestinal system (IPEC) or outside of it (ExPEC). Among the different pathogens, E. coli are becoming of great importance, and it has been suggested that ExPEC may harbor resistance genes that may be transferred to pathogenic or opportunistic bacteria. ExPEC strains are versatile bacteria that can cause urinary tract, bloodstream, prostate, and other infections at non-intestinal sites. In this context of rapidly increasing multidrug-resistance worldwide and a diminishingly effective antimicrobial arsenal to tackle resistant strains. ExPEC infections are now a serious public health threat worldwide. However, the clinical and economic impact of these infections and their optimal management are challenging, and consequently, there is an increasing awareness of the importance of ExPECs amongst healthcare professionals and the general public alike. This review aims to describe pathotype characteristics of ExPEC to increase our knowledge of these bacteria and, consequently, to increase our chances to control them and reduce the risk for AMR, following a One Health approach.

Keywords: Escherichia coli; ExPEC; virulence factors; antibiotic resistance

\section{Introduction}

Antimicrobial resistance (AMR) is a natural phenomenon linked to the creation and spread of resistance factors enhanced using antibiotics. The One Health approach emphasizes the importance of AMR's presence as a major concern both in public health and in food animal production systems [1,2]. Among the pathogens, E. coli is becoming of great importance, and it has been suggested that both Extraintestinal Pathogenic E. coli, (ExPEC) and commensal E. coli (CoEC) strains may harbor resistance genes that may be transferred to pathogenic or opportunistic bacteria [3,4]. Specifically, ExPEC strains are also gaining new and troubling antibiotic resistance genes [5]. Indeed, in this context of rapidly increasing multidrug-resistance worldwide and a diminishingly effective antimicrobial arsenal to tackle resistant strains, ExPEC infections are now a serious public health threat worldwide. However, the clinical and economic impact of these infections and their optimal management are challenging and, consequently, there is an increasing awareness of the importance of ExPECs amongst healthcare professionals and the general public alike [6-8]. This review aims to supply an organized description of ExPEC pathotypes characteristics to increase the knowledge of these bacteria and, consequently, increase our chances of controlling them and reducing the risk for AMR, following a One Health approach. 


\section{Escherichia coli}

Escherichia coli is a Gram-negative bacterium, facultative anaerobe, not sporogenous, belonging to the Enterobacterales order. It has a rod shape of roughly $0.4 \mu \mathrm{m}$ in diameter and 2-3 $\mu \mathrm{m}$ in length. It can be provided or not with a capsule and is generally mobile due to the peritric flagella. It grows in a wide range of temperatures $\left(15-45^{\circ} \mathrm{C}\right)$ and can survive in the environment for long periods [9].

E. coli is the main facultative anaerobe in the intestinal flora of humans and warmblooded animals and is generally non-pathogenic. Most of the E. coli strains isolated from 1895 to today are part of the commensal microbial population of the intestine; it is typically present in feces, in the amount of $10^{7}-10^{9} \mathrm{CFU} / \mathrm{g}$ and is usually the predominant microorganism in coprocultures of all mammals. Nevertheless, specific strains have developed pathogenetic mechanisms capable of causing several pathologies, even severe ones in humans and animals [10,11].

Strains of E. coli are serologically classified according to the antigenic differences of the $173 \mathrm{O}$ (somatic) and $56 \mathrm{H}$ (flagellar) antigens, based on the typing scheme introduced in 1947 by Kauffmann and still recognized and used internationally [12]. The set of bacterial strains characterized by the same $\mathrm{O}$ antigen constitutes a "serogroup", while a specific combination of $\mathrm{O}$ antigen and $\mathrm{H}$ antigen defines the "serotype" of an isolate. Additional antigens analyzed in the Kauffmann classification are the K (capsular) and F (fimbrial) antigens [9].

The clustering of an E. coli strain to a specific serogroup or serotype can be associated with the presence of certain pathogenetic factors and the ability to cause specific symptoms. However, the serotype alone cannot predict either the genotypic characteristics or the pathogenicity since the horizontal gene transfer allows strains with identical phenotypic characteristics (i.e., the serotype) to have several genotypic differences (i.e., different pathogenic factors). More recently, in addition to Kaufmann's classification scheme, E. coli have been classified into pathotypes based on their pathogenetic profile, which considers the virulence factors and the diseases caused mainly in humans [13]. Indeed, pathogenic E. coli can be distinguished from their non-pathogenic counterparts by the presence of virulence genes, which code for adherence, colonization, invasion, cell surface molecules, secretion, transport, and siderophore formation. These virulence genes are generally organized as large blocks in chromosomes, plasmids, or phages and are often transmissible between E. coli strains.

\section{Escherichia coli Pathotypes}

Based on this latter classification, E. coli can be distinguished into two main groups based on the ability to cause infection of the gastrointestinal system (Intestinal Pathogenic Escherichia coli, IPEC) or outside this (Extraintestinal Pathogenic Escherichia coli, ExPEC) (Figure 1). Among IPEC, E. coli strains are categorized into the following pathotypes: (1) enteropathogenic E. coli (EPEC), which causes diarrhea in children and animals; (2) enterohemorrhagic E. coli (EHEC), responsible for hemorrhagic colitis and hemolyticuremic syndrome; (3) enterotoxigenic E. coli (ETEC), the main cause of traveler's diarrhea and porcine and bovine diarrhea; (4) enteroaggregative E. coli (EAEC), that can cause persistent diarrhea in humans, and (5) diffusely adherent $E$. coli (DAEC), a subclass of enteroaggregative E. coli which causes diarrhea in children; (6) enteroinvasive E. coli (EIEC), which causes watery diarrhea and dysentery. EIEC and EAEC strains were found only in humans and not in animals [14]. 




Figure 1. Classification of extraintestinal and intestinal pathogenic E. coli variants. Abbreviations: intestinal pathogenic E. coli (IPEC), enteropathogenic E. coli (EPEC), enterohemorrhagic E. coli (EHEC), enterotoxigenic E. coli (ETEC), enteroaggregative E. coli (EAEC), diffusely adherent E. coli (DAEC), enteroinvasive E. coli (EIEC), extraintestinal pathogenic E. coli (ExPEC), uropathogenic E. coli (UPEC), neonatal meningitis E. coli (NMEC), sepsis-associated E. coli (SEPEC), avian pathogenic E. coli (APEC), and mammary pathogenic E. coli (MPEC).

The ExPEC group incorporates the following variants: uropathogenic E. coli (UPEC), neonatal meningitis E. coli (NMEC), those isolates responsible for septicemia (SEPEC), avian pathogenic E. coli (APEC) and mammary pathogenic E. coli (MPEC), [15]. These pathotypes are also isolated from animal diseases such as fatal pneumonia in pigs, mastitis in cows and pigs, pyometra, and urinary tract infections in dogs [16-18].

\section{Extraintestinal Pathogenic Escherichia coli, ExPEC}

ExPEC strains are versatile bacteria that can cause urinary tract, bloodstream, prostate, and other infections at non-intestinal sites. ExPEC strains are responsible for many human infections, both in healthcare-associated and community settings $[19,20]$. They typically occupy a niche in the intestinal microbiota of humans (and other animals), and from this reservoir, they emerge to cause extraintestinal infections [5]. Aside from these bacteriaspecific traits, additional factors are required for illness (i.e., host-specific factors) are also required for disease, and for this reason, ExPEC are considered a necessary but not sufficient cause for extraintestinal E. coli infections [21], and a limited set of ExPEC lineages are responsible for most infections [22].

ExPECs are most frequently implicated as urinary tract pathogens and they are the infective agent in up to $90 \%$ of both simple community-acquired urinary tract infections (UTIs) and pyelonephritis cases. Other urinary tract infections, including prostatitis and catheter-associated UTIs, are also frequently caused by ExPECs $[19,23,24]$. 
ExPECs are also implicated in infections originating from abdominal and pelvic sources, including, but not limited to, biliary infections, infective peritonitis, and pelvic inflammatory disease $[25,26]$. Hematogenous invasion of ExPEC from the initial infective focus results in sepsis syndrome, which may result in death in the absence of timely management [8].

\section{ExPEC Virulence Factors}

ExPEC virulence factors can be divided into five categories: adhesins, invasins, iron uptake factors, protectines, and toxins. The list of all the virulence factors and their presence within the different ExPEC pathotypes are reported in Table 1.

Table 1. Virulence genes, functions, and encoded virulence factors of ExPEC pathotype [27].

\begin{tabular}{|c|c|c|c|}
\hline Description & Virulence Genes & Function & ExPEC Pathotype \\
\hline \multicolumn{4}{|c|}{ Adhesins } \\
\hline Type 1 fimbriae & fim & $\begin{array}{c}\text { Factor of colonization in extraintestinal infections, } \\
\text { biofilm formation }\end{array}$ & UPEC, NMEC, SEPEC, APEC \\
\hline Afimbrial adhesin & $a f a$ & $\begin{array}{l}\text { The non-fibrous adhesin binds to the DAF receptor } \\
\text { on the cell } \\
\text { surface epithelium as well as type IV collagen and } \\
\text { members of the CEACAM family, } \\
\text { hemagglutination capacity }\end{array}$ & UPEC \\
\hline Dr fimbriae & $d r a$ & $\begin{array}{l}\text { Binding to the DAF receptor on the surface } \\
\text { epithelial cells as well as type IV collagen and } \\
\text { members of the CEACAM family, } \\
\text { mediation of internalization bacteria to the } \\
\text { host cells }\end{array}$ & UPEC \\
\hline P fimbriae & pap & $\begin{array}{l}\text { Stimulate the production of cytokines by } \mathrm{T} \\
\text { lymphocytes, colonization } \\
\text { factor in extraintestinal infections }\end{array}$ & UPEC, SEPEC, APEC \\
\hline S fimbriae & $s f a$ & $\begin{array}{l}\text { Adhesion to intestinal epithelial cells, kidney, } \\
\text { lower urinary tract } \\
\text { cells; facilitate the penetration of bacteria into } \\
\text { the tissues }\end{array}$ & UPEC, NMEC \\
\hline F1C fimbriae & foc & $\begin{array}{l}\text { Adhesion to renal epithelial cells and endothelial } \\
\text { cells of the bladder } \\
\text { and kidneys }\end{array}$ & UPEC \\
\hline Iha & iha & Iron-regulated-gene-homolog adhesion & UPEC \\
\hline Mat & mat & $\begin{array}{l}\text { Meningitis associated and temperature } \\
\text { regulated fimbriae }\end{array}$ & NMEC \\
\hline Curli fiber gene & $\operatorname{crl}, \operatorname{csg}$ & $\begin{array}{l}\text { Enable biofilm formation and } \\
\text { promote pathogenicity }\end{array}$ & UPEC, SEPEC, APEC \\
\hline Antigen 43 & $\operatorname{agn} 43(f l u)$ & $\begin{array}{l}\text { Protein of autotransporter family, adhesion and } \\
\text { biofilm development }\end{array}$ & UPEC \\
\hline \multicolumn{4}{|c|}{ Invasins } \\
\hline Ibe ABC & $i b e A, B, C$ & Cell invasion into the host tissues & NMEC, SEPEC, APEC \\
\hline \multicolumn{4}{|c|}{ Iron uptake } \\
\hline Aerobactin & iuc, aer & $\begin{array}{l}\text { Siderophore, acquisition of } \mathrm{Fe}^{+} / 3^{+} \text {in the } \\
\text { host system }\end{array}$ & UPEC, APEC \\
\hline $\begin{array}{l}\text { Iron repressible } \\
\text { protein }\end{array}$ & $\operatorname{irp}$ & Yersiniabactin synthesis & NMEC \\
\hline
\end{tabular}


Table 1. Cont.

\begin{tabular}{|c|c|c|c|}
\hline Description & Virulence Genes & Function & ExPEC Pathotype \\
\hline Salmochelin & iroN & $\begin{array}{l}\text { Siderophore receptor, use of Fe ions obtained } \\
\text { from the body host }\end{array}$ & UPEC, NMEC, SEPEC APEC \\
\hline ChuA, Hma & chu, hma & $\begin{array}{c}\text { Enable using of Fe from hemoglobin in the } \\
\text { host system }\end{array}$ & UPEC, SEPEC \\
\hline SitABC & sit $A, B, C$ & Transportation of Fe, Mn & UPEC, APEC \\
\hline \multicolumn{4}{|c|}{ Protectins/serum resistance } \\
\hline Transfer protein & $\operatorname{traT}$ & $\begin{array}{l}\text { Inhibition of the classical pathway of } \\
\text { complement activity }\end{array}$ & NMEC, SEPEC APEC \\
\hline Capsular antigens & $\begin{array}{l}\text { KpsMI-neuA, } \\
\text { KpsMII }\end{array}$ & $\begin{array}{c}\text { The protection factor against phagocytosis and } \\
\text { the spreading } \\
\text { factor }\end{array}$ & NMEC, SEPEC \\
\hline $\begin{array}{l}\text { Outer membrane } \\
\text { protein }\end{array}$ & ompA & $\begin{array}{l}\text { Enable intracellular survival, evasion from the } \\
\text { body's defense. }\end{array}$ & UPEC, NMEC \\
\hline $\begin{array}{l}\text { Increased serum } \\
\text { survival }\end{array}$ & iss & The protection factor against phagocytosis & NMEC, SEPEC, APEC \\
\hline ColV, CvaC & $\operatorname{colV}, \mathrm{cvaC}$ & Factor facilitating colonization & NMEC, SEPEC, APEC \\
\hline \multicolumn{4}{|c|}{ Toxins } \\
\hline $\begin{array}{l}\text { Serin protease } \\
\text { autotransporter }\end{array}$ & pic & $\begin{array}{c}\text { Degrades mucins, facilitates colonization } \\
\text { epithelium, damages of } \\
\text { the cell membrane }\end{array}$ & UPEC \\
\hline $\begin{array}{c}\text { Secreted } \\
\text { autotransporter toxin }\end{array}$ & sat & $\begin{array}{l}\text { Proteolytic toxin, effect cytotoxic-influences on } \\
\text { cell vacuolization }\end{array}$ & UPEC \\
\hline $\begin{array}{l}\text { Vacuolating } \\
\text { autotransporter toxin }\end{array}$ & vat & Proteolytic toxin induces host cell vacuolization & UPEC, APEC \\
\hline Hemolysin A & hlyA & $\begin{array}{l}\text { Creation of pores in membranes of host cells } \\
\text { (cell lysis) }\end{array}$ & UPEC \\
\hline $\begin{array}{l}\text { Cytotoxic necrotizing } \\
\text { factor }\end{array}$ & cnf & Engaging in cell necrosis & UPEC, SEPEC \\
\hline $\begin{array}{l}\text { Cytolethal distending } \\
\text { toxin }\end{array}$ & $c d t$ & Cytolethal distending factor & SEPEC \\
\hline
\end{tabular}

\subsection{Adhesins}

Many surface structures play a significant role in the process of specific adhesion. There are three main types of adhesins: fimbriae, afimbrial adhesins (Afa), and outer membrane proteins (OMPs) [28]. This family of adhesive and virulence-associated surface structures in Gram-negative bacteria is assembled and secreted by the chaperon-usher pathway, which involves the binding of nascent pilus subunits by a dedicated chaperone in the bacterial periplasm and the subsequent polymerization of subunits into the pilus fiber at the outer membrane by an integral outer membrane channel protein termed the usher [29]. The expression of surface adhesins increases the virulence of pathogenic E. coli by facilitating close contact of the bacteria with the host cell wall. Different bacterial adhesins are adapted to colonize specific niches. S-fimbrial adhesins ( $f f a$ ), F1C ("pseudotype $\left.\mathrm{I}^{\prime \prime}\right)$ fimbriae (foc), coding P-like pili, papC, and Iha (iha) are the most frequently detected adhesins among isolates from UTI patients [30]. For UPEC strains, P- and S- fimbriae receptors are located on the surface of epithelial cells lining the host urinary tract [31]. S-fimbrial adhesins are virulence factors present in strains responsible for meningitis and sepsis. These fimbriae can bind extracellular matrix components and sialoglycoproteins on brain capillary endothelial cells. NMEC is characterized by K1 capsular antigens (kpsM, neuA) or the $i b e A$ invasion gene. The relationship between the type of infection and the 
presence of characteristic virulence factors has been demonstrated, i.e., IbeA protein has surface receptors on the brain capillary endothelial cells and allows pathogens to invade the nervous system [32].

Fimbriae with an affinity for structures containing mannose residues were classified as type 1, and mannose resistant fimbriae as type 2 (e.g., P, S, Dr fimbriae). FimB and fimE genes are responsible for controlling the expression of type 1 fimbriae. Three other genes, i.e., fim F, fim $\mathrm{G}$, and $\mathrm{fim} H$ are involved in the adhesive property and longitudinal regulation. FimH adhesin, present on top of a fibrillum attached at the end of a pili rod composed of FimA proteins, binds to uroplakin 1A receptor (UP1a) of bladder epithelial cells, allowing invasion and formation of biofilm-like intracellular structures [33,34]. Mannose-resistant fimbriae include hemolytic F-type fimbriae, encoded by 11 genes in the pap genes cluster located on the chromosome. PapG adhesin occurs in 3 molecular variants: PapGI, PapGII, PapGIII, with PapGIII associated with bladder inflammation in women and children, and PapGII related to human bacteremia. The $\mathrm{P}$ fimbriae are also common virulence factors in renal transplant patients and patients with acute renal impairment $[35,36]$. According to Shetty et al. 2014, the high prevalence of adhesin-encoding genes from E. coli isolates in patients diagnosed with UTI confirms that these structures are necessary to cause an infection [27].

A significant group of superficial virulence factors found mainly in UPEC strains and associated with the occurrence of pyelonephritis and recurrent cystitis is the Afa/Dr family of adhesins, which contains both the fimbrial adhesins with Dr fimbriae and Afa [37]. draA, $d r a B, d r a C, d r a D$, and $d r a E(a f a A, a f a B, a f a C, a f a D, a f a E)$ genes encode a set of proteins responsible for the regulation of expression, activity as periplasmic chaperone, outer membrane usher, fimbrial tip subunit of unknown function, and adhesion/fimbrial subunit respectively. The receptor common for the whole family is the decay-accelerating factor (DAF), expressed on the surface of erythrocytes and cells of other tissues (e.g., the epithelium of the urinary tract) [38].

UpaG, a member of the auto-transporter family of adhesins, shows an affinity for fibronectin and laminin, allowing UPEC adherence to the bladder epithelium. Additionally, UpaG creates biofilm on plastics, which facilitates colonization of urological catheters [39]. Urinary tract infections can often cause bacteremia, especially in hospitalized patients, when biofilm is produced due to catheter contamination $(36,37)$. Moreover, the translocation of bacterial cells from the growth phase in plankton to the growth phase in the biofilm is associated with a change in the expression of many genes (e.g., flu and tibA) encoding virulence factors and regulatory proteins. The biofilm-forming ability of $E$. coli is affected by the expression of gene encoding antigenic Agn43, which is involved in the aggregation of $E$. coli cells [40].

\section{Biofilm}

Biofilms are dynamic assemblages of microorganisms that adhere to biotic or abiotic surfaces and are characterized by highly specialized interactions between microorganisms. The bacteria are embedded in a matrix of self-produced extracellular polymeric substances (EPS) which allows one to alter phenotypes (e.g., growth rate, gene transcription, and antibiotic resistance) [41,42]. Schematically, a model for the formation of a differentiated and mature bacterial biofilm requires five developmental stages: (i) a reversible attachment of planktonic bacteria to the solid surface; (ii) transition from reversible to irreversible attachment due to production of EPS and/or specific adhesins located on pili and fimbriae, which interact with the surface (e.g., flagella, autotransporter proteins, fimbriae, curli, EPS, and F-type conjugative pilus) [43-45]; (iii) early development of biofilm architecture. (iv) late development of microcolonies into a mature biofilm; (v) dispersion and detachment of cells from the biofilm into the environment. All these processes need to be highly regulated, for this reason, bacteria have evolved different cell-to-cell signaling molecules that are the main constituent of signaling pathways responsible for population density-dependent gene expression and biofilm formation. In Gram-negative bacteria, the 
molecules devoted to the cell-to-cell signaling are acylated homoserine lactones (AHLs, like $\mathrm{N}$-acyl-homoserine-lactone in Vibrio fischeri) expressed by luxI gene (firstly described in $V$. fischeri) that bind and activate LuxR protein and regulates the transcription of several genes involved in biofilm formation, expression of specific adhesins and metabolism [46]. E. coli (as well as Salmonella) does not contain luxI gene and is unable to synthesize AHLs; however, it expresses SdiA protein, similar to the LuxR-type transcriptional activator in AHL-dependent quorum-sensing, which makes E. coli biofilm regulation and synthesis susceptible to signaling molecules produced by other species [47]. Numerous E. coli strains can express the autoinducer-2 (AI-2) which is widespread in both Gram-negative and Gram-positive bacteria and regulates multiple functions such as the production of flagella and motility, but its expression is dependent on luxS gene product. The luxS / AI-2 system is one of the most widespread quorum-sensing systems (being described for the first time in Vibrio harveyi), LuxS is involved in the metabolism of S-adenosylmethionine (SAM) by converting in homocysteine and 4,5-dihydroxy-2,3-pentanedione (DPD), the cyclization of DPD generates several furanones including the precursor of AI-2 [46]. Different authors have demonstrated that AI-2 production is growth-phase dependent [48]. Currently, there are two types of AI-2 receptors, $\mathrm{LuxP}$ and $\mathrm{LsrB}$, which were initially described in $V$. harveyi and Salmonella typhimurium, respectively [49]. lsrB gene is contained in the lsr operon, which consists of eight genes (lsrKRACDBFG) devoted to an ATP binding cassette (ABC) transporter synthesis. LuxP is homologous to the ribose binding protein of E. coli and S. typhimurium and acts as the primary sensor for AI-2 [50]. In ExPEC strains, the tolC gene (which belongs to the outer membrane efflux protein (OEP) family devoted to maintaining the structure and function of the outer membrane) is essential for biofilm formation in response to altered osmolarity also via depleted curli production [51].

\subsection{Invasins}

The adhesion of E. coli to membrane receptors of host cells triggers a cascade of host-cell signal transduction pathways that result in host-cell actin cytoskeleton rearrangements required for bacterial invasion of Human Brain Microvascular Endothelial Cells (HBMEC) [52]. Regulation of the rearrangement of the host actin cytoskeleton by E. coli $\mathrm{K} 1$ is a complex multifactorial process involving host actin-binding proteins and signaling molecules, as well as specific microbial determinants [52]. However, the underlying host-microbial interactions in the bacterial invasion of HBMEC remain not entirely understood [53].

The Rho family of small GTPases such as RhoA, Rac1, and CDC42 have been shown to regulate host cytoskeleton organization, acting as molecular switches, and various pathogens (e.g., C. trachomatis, N. gonorrhoeae) have been shown to exploit the Rho GTPases to aid their entry into the host cells $[54,55]$.

Other invasins such as IbeA, belonging to the Pfam12831 family of FAD-dependent oxidoreductases and OmpA may contribute to HBMEC invasion via Rac1 activation [53]. The ibeA gene is located on the $20.3 \mathrm{~kb}$ island GimA, inserted between yjiD and yjiE, and proposed to contain four operons, some of which are potentially involved in energy metabolism [56]. This gene is not ubiquitous among E. coli; it is absent in non-pathogenic strains, $[57,58]$ and encodes a protein that plays an essential role in the invasion of ExPEC in Brain Microvascular Endothelial Cells (BMEC) and the invasion of intestinal epithelial cells. This gene might be relevant for bacterial survival [59]. Indeed, the inactivation of $i b e A$ in the NMEC and APEC strains has resulted in the defective invasion of BMEC both in vitro and in vivo [59-62]. It has been demonstrated that IbeA interacts with its receptor, an albumin-like protein, on the surface of both human $(45 \mathrm{kDa})$ and bovine $(55 \mathrm{kDa})$ BMEC. IbeA-binding protein was purified from intestinal epithelial Caco-2 cells [63-66]. IbeA could therefore be involved in the receptor ligand-mediated invasion of BMEC [58].

Considering what has been described before, it can be said that $i b e A$ is involved in the pathogenesis of several ExPEC pathotypes, including NMEC and APEC, and contributes 
to the invasion of ExPEC into host cells $[60,62]$. Furthermore, the IbeA receptor PSF was described for both human and bovine BMEC [63-66].

The results obtained by Wang et al. 2011 indicated that the loss of ibe $A$ resulted in reduced tissue-recovered bacteria than those of the wild-type strain [58]. Similarly, Germon et al. 2005 observed that the inactivation of $i b e A$ caused the reduction of the presence of bacteria in cells and blood [60]. This phenomenon might be due to the downregulation of other virulence factors, such as type 1 fimbriae, autotransporter adhesin $[67,68]$, and the invasion-associated gene $i b e B$ in the mutant strain, concluding that all these genes participate in the adhesion and invasion of APEC to host cells [58]. The inactivation of $i b e A$ decreases the expression level of virulence factors involved in invasion and adhesion, causing loss of colonization and proliferation capacities of APEC [58]. IbeA-negative strains showed impaired intramacrophage survival. This mechanism has not been elucidated anymore, but it is supposed that this gene could confer tolerance to reactive oxygen species (ROS) induced stress [69]. Finally, the presence of $i b e A$ in biofilm-forming strains has been observed, but no studies have shown that this gene is involved in biofilm formation [58].

\subsection{Iron Uptake Factors}

Siderophores are secondary metabolites that capture iron to enhance bacterial growth and development [70]. Iron deficiency weakens bacterial adaptive abilities by generating disturbances in cellular capsules structure and synthesis [71]. In ExPEC, access to iron in the blood serum is of paramount importance. Since $E$. coli can cause sepsis and infections of various organs with very low iron availability, this pathotype has developed many strategies to obtain iron from infected sites [72,73].

Siderophores can be divided into five main classes: catecholates, phenolates, hydroxamic acids, $\alpha$-hydroxycarboxylates, and a mixed type containing different siderophores. ExPECs are equipped with siderophores that increase their virulence: enterobactin and salmochelin (catecholate siderophores), aerobactin (a mixed-type siderophore), and yersiniabactin (phenolate siderophore).

\subsubsection{Enterobactin}

Enterobactin is produced by nearly all E. coli strains and produced by many other pathogenic enterobacteria, including Salmonella spp. and Klebsiella spp. [74,75]. The genes responsible for enterobactin biosynthesis and transport are grouped in a single contiguous gene cluster entEBG(AC) [74]. Enterobactin biosynthesis is a two-step process involving six genes responsible for the synthesis of six corresponding proteins [76]. First, 2,3dihydroxybenzoate (2,3-DHB) is synthesized from chorismate by EntC (isochorismate synthetase), EntB (isochorismatase), and EntA (dihydroxybenzoate deshydrogenase) [76-79]. Then, serine and 2,3-DHB are processed by an NRPS (nonribosomal peptide synthetase) enzymatic complex composed of EntB, EntE, and EntF, to form the final enterobactin molecule, corresponding to a cyclized DHBS (2,3-dihydroxybenzoylserine) triester [80-84]. This step also requires the phosphopantetheinyltransferase EntD to activate the thiolation domains of the NRPS systems and allow 2,3-DHB to bind to the assembly complex [81,85].

Enterobactin is found in both pathogenic and non-pathogenic E. coli [75] but seems to play some role in ExPEC virulence. A chicken experimental model of systemic infection using mutant E. coli strains (defective for aerobactin and salmochelin) producing only enterobactin showed attenuation of virulence [86,87]. The inefficacy has been attributed to the absorption of this protein by host immune defense proteins, such as human neutrophil gelatinase-associated lipocalin (NGAL). It has been demonstrated that modification of enterobactin through glycosylation by IroB results in the generation of salmochelins that can evade sequestration by NGAL [88]. Enterobactin glycosylation is, therefore, an important virulence mechanism through which certain pathogenic strains can evade host immune defenses and obtain iron [89]. 


\subsubsection{Salmochelin}

Salmochelin is found in ExPEC strains and is considered a characteristic virulence factor for this pathotype. It is encoded by the iroBCDEN gene cluster [90] located on ColV or ColBM virulence plasmids or identified on pathogenicity-associated islands (PAI) [91]. It has been reported that $i r o B$ is the sole gene with glycosyltransferase activity necessary for salmochelin production, which leads to glycosylation of enterobactin that changes its properties from strongly hydrophobic to hydrophilic. This chemical rearrangement may contribute to the virulence of ExPEC [92,93].

The IroB glycosyltransferase transfers glucosyl groups from uridine-50-diphosphoglucose to $\mathrm{C} 5$ residues of enterobactin 2,3-DHB [94], generating three types of cyclic salmochelins: monoglucosyl-C-enterobactin (MGE), diglucosyl-C-enterobactin (DGE), and triglucosyl-Centerobactin (TGE). Only IroB is required for the conversion of enterobactin into salmochelins [90,94]. However, six different linear forms of salmochelins can also be generated from cyclic salmochelins by the IroD, IroE, and Fes esterases [94,95]. The IroN salmochelin receptor plays a role in virulence of UTI strain CP9 and NMEC strain S88 [96-99] and the iroN gene is overexpressed in intracellular bacterial communities (IBC) found in urothelial cells infected with UPEC strain UTI89 in a mouse model of UTI [100]. Furthermore, deletion of the IroA locus in APEC strain x7122 resulted in decreased virulence in chicken experimental models [87].

\subsubsection{Aerobactin}

Aerobactin is another siderophore commonly harbored in ExPECs. Similar to salmochelin, this siderophore is also encoded by $\mathrm{ColV}$ and ColBM plasmids $[27,91]$ and its biosynthesis is driven by enzymes encoded by the iuc $A B C D$ (iron uptake chelate) genes [101]. From L-lysine, IucD monooxygenase forms N6-hydroxy-L-lysine [102]. Then, IucB acetyltransferase synthesizes N6-acetyl-N6-hydroxy-Llysine from N6-hydroxy-L-lysine and acetyl$\mathrm{CoA}$ [103]. IucA and IucC, respectively, participate in the acylation and condensation of N6-acetyl-N6-hydroxy-Llysine to produce aerobactin [104-106].

Compared to commensal strains, aerobactin biosynthetic genes are more frequently detected in pathogenic E. coli strains isolated from food-producing animals [107-109]. Moreover, compared to the wild-type, the virulence of an APEC strain, deficient in aerobactin synthesis and uptake, is reduced in a chicken systemic infection model [87]. It has also been shown that aerobactin contributes to iron uptake in vivo in a UTI model [110]. Compared to enterobactin, very low aerobactin concentrations are sufficient to stimulate bacterial growth. Moreover, enterobactin binds to albumin in serum with a consequent low amount of iron sequestered from transferrin; iron uptake by aerobactin is more efficient since it can acquire more iron from transferrin than enterobactin [111-113].

\subsubsection{Yersiniabactin}

ExPECs may also produce yersiniabactin, which was initially detected in Yersinia pestis (from which its name), mainly during colonization of the urinary tract. Yersiniabactin contributes to the pathogenicity of uropathogenic E. coli (UPEC), especially during colonization of the urinary tract, and may protect bacterial cells against host immune response $[27,114,115]$. It is synthesized by a mixed NRPS/PKS (polyketide synthase) system [116]. All the genes responsible for its biosynthesis are grouped in a gene cluster (MiBIG accession number: BGC0001055), except for the phosphopantetheylyl transferase that allows cysteines, salicylate, and malonyl precursors to bind to the assembly complex $[115,116]$. Briefly, salicylate is formed from chorismate by the Irp9 (YbtS) salicylate synthetase, it is then adenylated by YbtE to be transmitted to the NRPS/PKS system. The NRPS encoded by irp2 forms two thiazoline rings from cysteines. On the PKS encoded by irp1, a malonyl linker is incorporated and $\mathrm{YbtU}$ reduces one thiazoline ring to thiazolidine before cyclization and condensation of the final thiazoline ring. Then, the newly synthesized siderophore is released from the PKS thioesterase domain while the YbtT thioesterase performs its editing function by eliminating aberrant molecules [116]. 
Yersiniabactin is involved in establishing UTI, as it plays a significant role in iron uptake in vivo [110] and promotes biofilm formation in human urine at bladder level [117]. In addition, it also reduces ROS formation from polymorphonuclear leukocytes, monocytes, and macrophages by scavenging iron and preventing Haber-Weiss reactions [118]. Thus, yersiniabactin could play an important role in virulence by activating the host response and innate immune system [115].

\subsection{Protectines/Serum Resistance}

Protectines are a category of ExPEC's virulence factors responsible for the characteristic serum resistance of these bacteria. Among all the known protectines, in this review, we focused on three resistance determinants: TraT, OmpA, and the capsular antigen $\mathrm{K}$.

\subsubsection{TraT}

TraT is one of the genes in the tra operon, a genetic unit involved in the transfer of the $\mathrm{R}$ factor, which is the conjugative plasmid (F plasmid) of E. coli $[119,120]$. The traT gene product is an outer membrane protein of $23 \mathrm{kDa}$ (present at 20,000 to 30,000 copies per cell) noncovalently associated with peptidoglycan that behaves similarly to several peptidoglycan associated lipoproteins. It exists in the membrane as multimeric aggregates with a substantial portion exposed on the external face of the cell's outer membrane [120-124]. TraT grants bacteria protection from the lytic action of complement and has several properties in common with other major outer membrane proteins, particularly the porins [123]. The oligomeric form of this protein is highly resistant to denaturation at temperatures below 70 to $80{ }^{\circ} \mathrm{C}$, digestion by trypsin or pronase in outer membrane fractions, and solubilization by a variety of detergents [121,125].

The role of TraT in serum resistance is to inhibit the correct assembly or membrane insertion of the membrane attack complex of complement [126]. The TraT protein has also been reported to reduce the susceptibility of wild-type E. coli cells to phagocytosis by mouse peritoneal macrophages [127]. Another peculiar characteristic of the F plasmid in E. coli cells is the surface exclusion, defined as the reduced ability of a strain carrying a conjugative plasmid to act as a recipient in conjugation with cells carrying identical or closely related plasmids. Therefore, cells carrying the F plasmid typically have a 100- to 300 -fold reduction in their ability to act as recipients relative to an F negative cell $[120,128]$. TraT protein blocks conjugation at an earlier stage before the cells have formed stable mating aggregates [121].

\subsubsection{OmpA}

Outer membrane proteins (OMPs) and lipoproteins have many functions, including membrane structure and stability, signal transduction, active and passive ion, and solute transport, defense, and catalysis [129]. In addition, most OMPs are surface exposed and are potentially critical in bacteria interactions with the mammalian host and its defense mechanisms, bacteriophages, and other bacteria or microorganisms [130].

Outer membrane protein A (OmpA) is a major heat modifiable OMP in E. coli and is one of the most characterized OMPs. Its molecular mass is $33 \mathrm{kDa}$ [131] and its structure is characterized by an N-terminal domain that forms an eight-stranded, anti-parallel $\beta$-barrel, which is embedded in the outer membrane noncovalently anchored to peptidoglycan and confers porin activity [132-134]. The C-terminal domain of OmpA is globular and located in the periplasmic space to interact with peptidoglycan $[135,136]$. OmpA has both structural and ion-permeable porin roles, with its ionic pore controlled by a salt-influenced electrostatic gating mechanism that allows bacterial survival during osmotic stress [137]. OmpA expression is closely associated with the expression of type 1 fimbriae, confirmed that ompA deleted mutants showed the suppression of type 1 fimbriae expression [138].

The importance of OmpA in pathogenicity has been established in numerous experimental models. Weiser and Gotschlich (1991) demonstrated that ompA-deficient E. coli K-1 (meningitic strain) was less virulent in a chick embryo and neonatal rat model and more 
sensitive to serum complement-mediated bactericidal effects [139]. OmpA is a virulence factor in meningitic strains of E. coli and has a function in adhesion to and invasion of the central nervous system, capillary endothelium, and astrocytes [140-142]. OmpA and its homologs are also involved in adhesion to epithelial cells on mucosal surfaces. Furthermore, OmpA mediates adhesion to leukocytes and macrophages in pathogenic strains of E. coli [130].

Through OmpA and its homologs, several pathogenic bacteria have mechanisms to escape host normal serum proteins and antibodies [143-146]. This is accomplished by binding the complement fluid-phase regulated protein C4B by E. coli (especially logarithmic-phase E. coli) [143]. OmpA-positive E. coli K1 induces the antiapoptotic factor Bclxl that blocks cytochrome $\mathrm{C}$ release and prevents macrophage apoptosis, thus assuring the survival of both macrophage and intracellular bacteria [147]. In addition, OmpA reduces proinflammatory cytokine production by interference with NF-kB activation $[148,149]$.

Nicholson et al. (2009) demonstrated that OmpA is critical for promoting persistent infection within the epithelium [150]. Indeed, OmpA expression in wild-type bacteria was increased 20-30 fold between 16 and $24 \mathrm{~h}$ after infection during urinary tract infection. Furthermore, E. coli ompA deficient mutants adhered and invaded bladder epithelium significantly reduced bacterial load compared to wild-type strains [151]. OmpA deficient E. coli were more susceptible than the wild-type strain to neutrophil-derived antibacterial peptide lactoferricin (a lactoferrin-derived antimicrobial peptide) and pulmonary surfactant proteins A and D (collectins), which increase membrane permeability [152,153].

In NMEC the central role of OmpA in adherence and invasion was demonstrated using ompA-deficient mutants and concluding a 25-50 times reduction in invasion compared to non-deficient strains [140,141].

\subsubsection{Capsular Antigens}

The bacterial capsule is an extracellular structure that microscopy can view as an extensive layer surrounding the cell [154]. The capsule is required to prevent the host immune system, and strains without capsules are usually non-pathogenic [155]. The presence of a capsule showed to be a key mechanism used by Gram-negative bacteria to evade phagocytosis [155].

The capsule is made up of long polysaccharide chains known as capsular polysaccharides (CPS), linear polymers of repeating carbohydrate subunits that sometimes also include a prominent amino acid or lipid component [156], which are typically negatively charged and generate a highly hydrated capsular layer. In some E. coli isolates, this layer can extend from the cell surface for approximately 100-400 nm [154]. Polyprenol-linked CPS repeat units are synthetized in the cytoplasm, flipped across the inner membrane by a Wzx protein, and polymerized into the full-length CPS by a Wzy protein. After export, the CPS chains are assembled into a capsule structure on the cell surface but it is not entirely clear how they are retained, and the process may be multifactorial [157].

The capsules of most ExPEC strains are thin, patchy, acidic, thermostable, and highly anionic, characteristics that identify group II polysaccharides [156,158]. Among over 80 different identified capsular (K) antigens [159] K1 and K2 are considered major determinants of ExPEC serum resistance [160,161]. The degree of serum resistance of K+ strains has been reported to be proportional to the amount of capsular material present [162] and to vary with the K type $[163,164]$. The role of K-capsule in serum resistance in vitro and in vivo within animal models is well-known [165-167]. The diversified structure of polysaccharide capsules produced by several dozen types of UPEC strains allows mimicking host tissue components and making immune system recognition difficult [35]. For example, E. coli strains expressing the capsular antigen are associated with the development of neonatal sepsis [168]. Capsular antigen $\mathrm{K}$ that covers the bacterial cell surface may inhibit adhesion to epithelial cells. The interaction of FimF with d-mannose inhibits the transcription of capsid genes, which may lead to a reduced amount of $\mathrm{K}$ antigen on the surface of the E. coli cell, and, as a result, facilitate the adhesion process [169]. 
While lipopolysaccharide (LPS) and other bacterial surface components readily bind $\mathrm{C} 3 \mathrm{~b}$, and the complement proteins can penetrate a capsular layer, the presence of a CPS layer effectively masks the underlying opsonized cell surface [170]. However, even within a single capsular serotype (e.g., E. coli K1), the extent of protection from opsonization may vary [171]. In addition, capsular polysaccharide blocks opsonization as it interferes with complement deposition in a dose-dependent way [172,173].

Some CPSs do not elicit an immune response even when conjugated to a carrier protein [174], and for this reason, they are called molecular mimics because they have the same structure as human glycans [175]. For example, E. coli K1 CPSs consist of a 2,8-linked polysialic acid which is identical to the polysialic acid found on neuronal and immune cells [155]. Once bacteria are internalized, phagosome-lysosome fusion leads to lysis of the bacterial cell; however, some bacteria such as E. coli $\mathrm{K} 1$ can survive and multiply within phagocytic and epithelial cells [176-179]. Endosomes containing these encapsulated bacteria acquire endosomal markers, which are characteristic of the early and late phases of the endosome but do not fuse with lysosomes. The mechanism behind this is unknown but probably is due entirely to the presence of CPS as isogenic acapsular mutants are effectively degraded in lysosomes [155]. The degree of impairment of phagocytosis is proportional to the amount of polysaccharides [172]. Phagocytosis of K1 strains increases after exposure to anti-K1 antibodies [172,180] or disruption of capsular polysaccharides by heating [181]. The anti-complement activity of capsular polysaccharides may also increase the survival in serum of some encapsulated strains [182,183].

\subsection{Toxins}

The most frequently detected genes encoding toxins in ExPECs are: $h l y A, h l y D, h l y F$ ( $\alpha$-hemolysin), cnf1 (cytotoxic necrotizing factor 1 ), sat (secreted autotransporter toxin), pic (protease involved in colonization), and vat (vacuolating autotransporter protein) [184-190].

\subsection{1. $\alpha$-Hemolysin}

The hemolysin is a toxin expressed by the operon $h l y C A B D$. The secreted HlyA protein is $110 \mathrm{kDa}$ [191]. HlyA is post-transcriptionally heterogeneously modified through the enzymatic activity of hlyC. The acylation is required for hemolytic and cytotoxic activities, but the modification is not required for extracellular secretion. The immature (unacylated) and mature forms of the hemolysin are respectively referred to as proHlyA and HlyA. The $h l y B$ and $h l y D$ genes encode proteins involved in the cytoplasmically modified HlyA polypeptide secretion across the inner and outer membranes without amino-terminal cleavage of the polypeptide [191]. These proteins form a type I secretion complex together with the TolC unlinked gene product [192]. The secretion pathway of E. coli hemolysin is generally considered the prototypical type I secretion protein among Gram-negative bacteria [193].

E. coli hemolysin appears to be cytotoxic to many different host-cell types and towards many hosts, both animals and humans. The target and host-cell specificity could be due to the sequence and $\mathrm{N}$-linked oligosaccharide-modification differences in the primary receptors for the toxins, $\beta 2$ integrins, on immune cells [194-196]. The mechanism for E. coli hemolysin cytotoxicity involves the formation of membrane pores. Therefore, when erythrocytes are used as target cells, loss of intracellular $\mathrm{K}^{+}$ions and subsequent influx of cations and water leads to osmotic lysis $[197,198]$. The initial pore formation leads to partial lysis of erythrocytes and subsequently triggers purinergic-receptor activation and creates a host-mediated pannexin pore. These events lead to the complete lysis of the cells.

There are several studies on the effects of the E. coli hemolysin on host cells in vitro, and it is difficult to assess which are relevant to the pathogenesis of UPEC. It seems unlikely that the lysis of erythrocytes is significant, although the canonical hypothesis is that the release of iron-containing heme molecules plays an important role in disease pathogenesis. As for the E. coli hemolysin activity against other host-cell types, several variables confound interpretations and conclusions about its role in uropathogenesis. The most significant 
variable is the presence of LPS in E. coli hemolysin preparations for in vitro experiments. In general, at low, sub-lytic, or apoptotic-inducing concentrations, the hemolysin triggers proinflammatory events [199-201].

\subsubsection{Cytotoxic Necrotizing Factor 1}

CNF1 was initially described as a toxin causing dermonecrosis when CNF-producing E. coli strains were intradermally injected in rabbits. Historically, its first described cytotoxic activity was the formation of multi-nucleated cells in culture [202]. CNF1 is a $115 \mathrm{kDa}$ protein that catalyzes the deamidation of a conserved-glutamine residue in three members of the Rho family of GTP-binding proteins. This leads to the activation of three specific GTPases: RhoA, Cdc42, and Rac [203,204]. The CNF1 protein is divided into three functional domains [205]. The enzymatic C-terminal half of the CNF1 polypeptide is present in the host cytosol after cleavage and release from late endosomes [206]. The very $\mathrm{N}$-terminal CNF1 domain appears to be responsible for binding to a laminin receptorprecursor protein $[207,208]$. An internal CNF1 domain is responsible for translocation across the endosomal membrane [209]. The activation of these regulators leads to cytoskeleton rearrangements, cell cycle disruption, and interruption of host-cell signaling pathways [210].

Epidemiologically, CNF1 production is more often associated with UPEC strains responsible for more severe UTIs; Andreu et al. showed that $48 \%$ of the pyelonephritis isolates were $\mathrm{cnf1}$ positive [211]. As is the case for hemolysin, the role of CNF1 in uropathogenesis is not entirely known, despite the evidence that it induces neutrophil dysfunction and increased epithelial-cell invasion [212].

\subsubsection{Type V Secretion Family}

The UPEC-toxin SPATE-family member that has received the greatest attention is the secreted autotransporter toxin (Sat). The sat gene is present, along with the hemolysin and pap pili determinants, within the large $p h e V$-associated pathogenicity island of UPECmodel strain CFT073. The sat gene encodes a $142 \mathrm{kDa}$ protein that possesses the three characteristic domains of SPATE proteins [213]. Guyer et al. demonstrated that Sat showed strong cytopathic effects on cultured cells and, in the murine model of UTI, histopathological lesions in the kidney can be ascribed to this protein [214]. In 2006 Maroncle et. Al. showed that a CFT073 Sat mutant did not have a statistically significant reduction in bacterial load either in the bladder or in the kidney compared to the parent strain CFT073and also showed, through the construction of active mutants, that Sat proteolytic activity was responsible for the cytotoxic activity, cytoskeleton rearrangements, and proteolysis of host proteins [213]. Moal et al. [215] showed that, in cultured HeLa cells, the Sat proteolytic activity initiates the disorganization of F-actin, resulting in detachment of the cell monolayers and loosening of cell-to-cell junctions. Furthermore, these events induce host-cell autophagy. Sat may also contribute to the exfoliation of the urothelial cells, an event commonly seen in UTIs model [212].

Two other SPATE family members, Pic and Vat, are commonly found in UPEC, and they were described in Shigella flexneri and APEC, respectively $[216,217]$. In UPEC model strain CFT073, the genes for these two autotransporter toxins (AT) are located respectively at the asp $V$ - and thrW-associated pathogenicity islands. Pic possesses mucinase activity towards O-linked glycoproteins, such as CD43, CD45, and fractalkine, commonly found on neutrophil surfaces [218]. Vat is a vacuolating AT toxin that occurs in more than half of E. coli isolates causing cystitis and pyelonephritis [219]. There are no reports about the significance of Vat in UPEC in vitro or in vivo model systems. However, it has been demonstrated to be a significant virulence factor in APEC using respiratory- and cellulitis infection models in broiler chickens [217]. 


\section{Antimicrobial Resistance (AMR)}

AMR results in reduced efficacy of antimicrobials, making the treatment of patients costly and difficult, or even impossible [220]. In some cases, resistance extends to the therapeutic agents' entire repository, posing a formidable challenge to antimicrobial therapy, bringing us back to the pre-antibiotic era [221,222].

Due to its particular ecology, E. coli can be considered a sensor of antimicrobial resistance. This organism has consolidated resistance traits that appeared many years ago, like TEM-1 $\beta$-lactamase, as well as the "newer $\beta$-lactamases" (Table 2 ) that consist of plasmid-mediated AmpC $\beta$-lactamases (e.g., CMY), extended-spectrum $\beta$-lactamases (e.g., CTX-M), and carbapenemases (e.g., NDM) [5,223-225].

Table 2. New $\beta$-lactamases found in E. coli. [15].

\begin{tabular}{|c|c|c|c|c|}
\hline Enzymes & Classification & Examples & $\begin{array}{l}\text { Spectrum of } \\
\text { Resistance }\end{array}$ & Inhibition \\
\hline $\begin{array}{l}\text { Extended-spectrum } \\
\beta \text {-lactamases(ESBLs) }\end{array}$ & Class A & CTX-M, TEM, SHV & $\begin{array}{l}\text { Penicillins } \\
\text { Cephalosporins } \\
\text { Monobactams }\end{array}$ & $\begin{array}{l}\text { Clavulanic acid, } \\
\text { Avibactam, } \\
\text { Vaborbactam, } \\
\text { Relebactam, } \\
\text { Tazobactam, } \\
\text { Sulbactam }\end{array}$ \\
\hline $\begin{array}{l}\text { Plasmid-mediated } \\
\text { AmpC } \beta \text {-lactamases }\end{array}$ & Class C & $\begin{array}{l}\text { CMY, FOX, } \\
\text { ACT, MOX } \\
\text { ACC, DHA }\end{array}$ & $\begin{array}{c}\text { Penicillins } \\
\text { Cephalosporins } \\
\text { Monobactams } \\
\text { Cephamycins }\end{array}$ & $\begin{array}{l}\text { Cloxacillin, } \\
\text { Boronic acid }\end{array}$ \\
\hline $\begin{array}{c}\text { Metallo- } \beta- \\
\text { lactamases(MBLs) }\end{array}$ & Class B & $\begin{array}{l}\text { IMP, VIM, } \\
\text { NDM }\end{array}$ & $\begin{array}{l}\text { Penicillins } \\
\text { Cephalosporins } \\
\text { Cephamycins } \\
\text { Carbapenems }\end{array}$ & $\begin{array}{l}\text { Metal chelators, e.g., } \\
\text { EDTA and } \\
\text { dipicolinic acid }\end{array}$ \\
\hline KPC carbapenemases & Class A & KPC & $\begin{array}{l}\text { Penicillins } \\
\text { Cephalosporins } \\
\text { Cephamycins } \\
\text { Carbapenems }\end{array}$ & $\begin{array}{c}\text { Clavulanic acid (weak), } \\
\text { Avibactam, } \\
\text { Vaborbactam, } \\
\text { Relebactam, } \\
\text { Tazobactam, } \\
\text { Boronic acid }\end{array}$ \\
\hline OXA- $\beta$-lactamases & Class D & OXA-48, -181 & $\begin{array}{c}\text { Penicillins } \\
\text { Temocillin } \\
\beta \text {-lactamase } \\
\text { combinations } \\
\text { Carbapenems }\end{array}$ & $\begin{array}{l}\text { Clavulanic acid, } \\
\text { Avibactam, } \mathrm{NaCl}\end{array}$ \\
\hline
\end{tabular}

In a 2014 report from the WHO, E. coli has been included in a list of the top nine microorganisms of international concern causing the most common infections in different settings: in the community, in hospitals, or transmitted through the food chain [222].

The cephalosporins, fluoroquinolones, and trimethoprim-sulfamethoxazole are often used to treat community and hospital E. coli infections, and resistance to these agents is responsible for delays in appropriate therapy with subsequently increasing morbidity and mortality [226,227]. Several surveillance studies during the 2000s across Europe, North and South America have shown that between 20 and 45\% of ExPECs are resistant to first-line antibiotics, including cephalosporins, fluoroquinolones, and trimethoprimsulfamethoxazole [228]. This problem undoubtedly must be controlled by a One Health approach, as the role of food-producing animals and the environment is not negligible $[4,229]$. $\beta$-Lactam antibiotics, especially the 3rd generation cephalosporins, are a major drug class used to treat severe community-onset or hospital-acquired infections involving E. coli [230]. Unfortunately, among E. coli, $\beta$-lactamase production remains the most important mediator of $\beta$-lactam resistance. $\beta$-lactamases are bacterial enzymes that inactivate $\beta$-lactam 
antibiotics by hydrolysis, resulting in the compound's inefficiency [230]. These enzymes can hydrolyze penicillins, cephalosporins, and monobactams, but not the cephamycins and carbapenems, and are inhibited by traditional $\beta$-lactamase inhibitors clavulanic acid, sulbactam, and tazobactam [231].

Since the mid-2000s, CTX- M $\beta$-lactamases had been identified in different family members of Enterobacteriaceae, especially in E. coli, and have become the most widespread type of extended-spectrum $\beta$-lactamases (ESBL) [232]. Risk factors associated with infections caused by CTX-M-producing E. coli include the following: repeated UTIs, underlying renal pathology, previous use of antibiotics including cephalosporins and fluoroquinolones, previous hospitalization, diabetes mellitus, underlying liver pathology, and international travel to high-risk areas such as the Indian subcontinent [233].

E. coli possesses a chromosomal gene that encodes for an AmpC $\beta$-lactamase. Usually, low amounts of these $\beta$-lactamases are produced because the AmpC gene is regulated by a weak promoter and a strong attenuator [234]. AmpC enzymes are not inhibited by traditional $\beta$-lactamase inhibitors such as clavulanic acid, sulbactam, and tazobactam, although boronic acids and cloxacillin have shown a good level of inhibition [235]. Risk factors associated with infection of AmpC $\beta$-lactamase-producing bacteria are not as well defined as those associated with ESBL-producing bacteria [236].

A new type of metallo $\beta$-lactamase (MBL), named New Delhi metallo- $\beta$-lactamase-1 (NDM-1), was described in K. pneumoniae and E. coli recovered from a Swedish patient who was hospitalized in New Delhi, India [237]. MBLs can hydrolyze a wide variety of $\beta$ lactams, including penicillins, cephalosporins, and carbapenems, but not the monobactams (e.g., aztreonam), and are inhibited by metal chelators such as EDTA. Unfortunately, most NDM-1-producing bacteria are broadly resistant to various drug classes and carry various other resistance mechanisms (e.g., aminoglycosides and fluoroquinolones), leaving limited treatment options [221].

Enterobacteriaceae with NDM-1 have been recovered from many clinical settings, reflecting the disease spectra of these opportunistic bacteria, including hospital and communityonset UTIs, septicemia, pulmonary infections, peritonitis, device-associated infections, and soft tissue infections $[221,238,239]$. There is no evidence that NDM-1 producing E. coli are more virulent than other isolates; however, recent studies described the presence of NDM-1 $\beta$-lactamases in E. coli ST131 with an identical virulence genotype compared to ST131 producing CTX-M $\beta$-lactamases [240]. ST131 with VIM and KPC carbapenemases have also been described [241,242]. Due to the very resistant nature of these NDM-producing E. coli, the treatment of infections due to these bacteria will remain a great challenge. Antibiotics such as colistin, tigecycline, and fosfomycin show the best activity against NDM-producing bacteria [239]. However, Stone et al. (2011) described breakthrough bacteremia caused by $E$. coli that produce NDM while the patient was treated with tigecycline; the isolate developed resistance to tigecycline [243]. AMR is a major threat to public health, and its mechanisms of spread both in animals and humans still need to be addressed.

\section{Conclusions}

This review describes the wide spectrum of virulence factors deployed by ExPEC and emphasizes the potential pathogenic role of these pathogens both for humans and animals and the risk associated with the spread of AMR genes, harbored and transferred by these pathogens bacteria. The information may be helpful to characterize ExPEC isolates better and may be considered a starting point for future studies aiming to increase our knowledge on the relationship between ExPEC virulence factors and AMR applying a One Health approach.

Author Contributions: Conceptualization, V.M.S. and A.Z.; methodology, V.M.S. and G.M.; writingoriginal draft preparation, V.M.S., G.M. and P.A.M.; writing—review and editing, A.Z., A.S. and L.B.; visualization, V.M.S.; supervision, A.Z., A.S. and L.B. All authors have read and agreed to the published version of the manuscript. 
Funding: The preparation of this manuscript was supported by Italian Ministry of Research and University (MUR) PRIN 2017 grant no. 2017MZ5KWM (to L.B).

Conflicts of Interest: The authors declare no conflict of interest.

\section{References}

1. World Health Organization. Global Antimicrobial Resistance and Use Surveillance System (GLASS) Report; WHO: Geneva, Switzerland, 2020; ISBN 978-92-4-002733-6.

2. $\quad$ E.U. A European One Health Action Plan against Antimicrobial Resistance (AMR); European Commission: Brussels, Belgium, 2018.

3. Sørum, H.; Sunde, M. Resistance to Antibiotics in the Normal Flora of Animals. Vet. Res. 2001, 32, 227-241. [CrossRef] [PubMed]

4. Dell'Orco, F.; Gusmara, C.; Loiacono, M.; Gugliotta, T.; Albonico, F.; Mortarino, M.; Zecconi, A. Evaluation of Virulence Factors Profiles and Antimicrobials Resistance of Escherichia coli Isolated from Bulk Tank Milk and Raw Milk Filters. Res. Vet. Sci. 2019, 123, 77-83. [CrossRef]

5. Manges, A.R.; Geum, H.M.; Guo, A.; Edens, T.J.; Fibke, C.D.; Pitout, J.D.D. Global Extraintestinal Pathogenic Escherichia coli (ExPEC) Lineages. Clin. Microbiol. Rev. 2019, 32, 1-25. [CrossRef] [PubMed]

6. Suskind, A.; Saigal, C.; Hanley, J.; Lai, J.; Setodji, C.; Clemens, J. Incidence and Management of Uncomplicated Recurrent Urinary Tract Infections in a National Sample of Women in the United States. Urology 2016, 90, 50-55. [CrossRef]

7. François, M.; Hanslik, T.; Dervaux, B.; Le Strat, Y.; Coignard, B.; Souty, C.; Vaux, S.; Maugat, S.; Rondet, C.; Sarazin, M.; et al. The Economic Burden of Urinary Tract Infections in Women Visiting General Practices in France: A Cross-Sectional Survey. BMC Health Serv. Res. 2016, 16, 1-10. [CrossRef]

8. Dale, A.P.; Woodford, N. Extra-Intestinal Pathogenic Escherichia coli (ExPEC): Disease, Carriage and Clones. J. Infect. 2015, 71, 615-626. [CrossRef]

9. Poli, G.; Cocilovo, A.; Dell'Ara, P.E.; Martino, P.A.; Ponti, W. Microbiologia e immunologia veterinaria. In Microbiologia e Immunologia Veterinaria; UTET Scienze Mediche: Milan, Italy, 2005; ISBN 8802070342.

10. Gyles, C.L.; Prescott, J.F.; Songer, J.G.; Thoen, C.O. Pathogenesis of Bacterial Infections in Animals, 4th ed.; Wiley-Blackwell: Hoboken, NJ, USA, 2010; ISBN 9780813812373.

11. Gomes, T.A.T.; Elias, W.P.; Scaletsky, I.C.A.; Guth, B.E.C.; Rodrigues, J.F.; Piazza, R.M.F.; Ferreira, L.C.S.; Martinez, M.B. Diarrheagenic Escherichia coli. Braz. J. Microbiol. 2016, 47, 3-30. [CrossRef] [PubMed]

12. Kauffman, F. The Serology of the Coli Group. J. Immunol. 1947, 57, 71-100.

13. Nataro, J.P.; Kaper, J.B. Diarrheagenic Escherichia coli. Clin. Microbiol. Rev. 1998, 11, 142-201. [CrossRef] [PubMed]

14. Palaniappan, R.U.M.; Zhang, Y.; Chiu, D.; Torres, A.; DebRoy, C.; Whittam, T.S.; Chang, Y.F. Differentiation of Escherichia coli Pathotypes by Oligonucleotide Spotted Array. J. Clin. Microbiol. 2006, 44, 1495-1501. [CrossRef]

15. Pitout, J.D.D. Extraintestinal Pathogenic Escherichia coli: A Combination of Virulence with Antibiotic Resistance. Front. Microbiol. 2012, 3, 1-7. [CrossRef] [PubMed]

16. Kong, L.-C.; Guo, X.; Wang, Z.; Gao, Y.-H.; Jia, B.-Y.; Liu, S.-M.; Ma, H.-X. Whole Genome Sequencing of an ExPEC That Caused Fatal Pneumonia at a Pig Farm in Changchun, China. BMC Vet. Res. 2017, 13, 169. [CrossRef] [PubMed]

17. Müştak, H.K.; Günaydin, E.; Kaya, İ.B.; Salar, M.Ö.; Babacan, O.; Önat, K.; Ata, Z.; Diker, K.S. Phylo-Typing of Clinical Escherichia coli Isolates Originating from Bovine Mastitis and Canine Pyometra and Urinary Tract Infection by Means of Quadruplex PCR. Vet. Q. 2015, 35, 194-199. [CrossRef] [PubMed]

18. Gerjets, I.; Traulsen, I.; Reiners, K.; Kemper, N. Comparison of Virulence Gene Profiles of Escherichia coli Isolates from Sows with Coliform Mastitis and Healthy Sows. Vet. Microbiol. 2011, 152, 361-367. [CrossRef]

19. Foxman, B.; Brown, P. Epidemiology of Urinary Tract Infections: Transmission and Risk Factors, Incidence, and Costs. Infect. Dis. Clin. N. Am. 2003, 17, 227-241. [CrossRef]

20. Russo, T.A.; Johnson, J.R. Medical and Economic Impact of Extraintestinal Infections Due to Escherichia coli: Focus on an Increasingly Important Endemic Problem. Microbes Infect. 2003, 5, 449-456. [CrossRef]

21. Singer, R.S. Urinary Tract Infections Attributed to Diverse ExPEC Strains in Food Animals: Evidence and Data Gaps. Front. Microbiol. 2015, 6, 1-9. [CrossRef] [PubMed]

22. Riley, L.W. Pandemic Lineages of Extraintestinal Pathogenic Escherichia coli. Clin. Microbiol. Infect. 2014, 20, 380-390. [CrossRef] [PubMed]

23. Talan, D.A.; Stamm, W.E.; Hooton, T.M.; Moran, G.J.; Burke, T.; Iravani, A.; Reuning-Scherer, J.; Church, D.A. Comparison of Ciprofloxacin (7 Days) and Trimethoprim-Sulfamethoxazole (14 Days) for Acute Uncomplicated Pyelonephritis Pyelonephritis in Women: A Randomized Trial. JAMA 2000, 283, 1583-1590. [CrossRef]

24. Brede, C.M.; Shoskes, D.A. The Etiology and Management of Acute Prostatitis. Nat. Rev. Urol. 2011, 8, 207-212. [CrossRef]

25. Chen, Y.-H.; Hsueh, P.-R. Changing Bacteriology of Abdominal and Surgical Sepsis. Curr. Opin. Infect. Dis. 2012, 25, 590-595. [CrossRef]

26. Sharma, H.; Tal, R.; Clark, N.A.; Segars, J.H. Microbiota and Pelvic Inflammatory Disease. Semin. Reprod. Med. 2014, 32, 43-49. [CrossRef]

27. Sarowska, J.; Futoma-Koloch, B.; Jama-Kmiecik, A.; Frej-Madrzak, M.; Ksiazczyk, M.; Bugla-Ploskonska, G.; Choroszy-Krol, I. Virulence Factors, Prevalence and Potential Transmission of Extraintestinal Pathogenic Escherichia coli Isolated from Different Sources: Recent Reports. Gut Pathog. 2019, 11, 1-16. [CrossRef] 
28. Lindberg, S.; Xia, Y.; Sondén, B.; Göransson, M.; Hacker, J.; Uhlin, B.E. Regulatory Interactions among Adhesin Gene Systems of Uropathogenic Escherichia coli. Infect. Immun. 2008, 76, 771-780. [CrossRef] [PubMed]

29. Werneburg, G.T.; Thanassi, D.G. Pili Assembled by the Chaperone/Usher Pathway in Escherichia coli and Salmonella. EcoSal Plus 2018, 8, 1. [CrossRef] [PubMed]

30. Hagan, E.C.; Mobley, H.L.T. Uropathogenic Escherichia coli Outer Membrane Antigens Expressed during Urinary Tract Infection. Infect. Immun. 2007, 75, 3941-3949. [CrossRef] [PubMed]

31. Mulvey, M.A. Adhesion and Entry of Uropathogenic Escherichia coli. Cell. Microbiol. 2002, 4, 257-271. [CrossRef] [PubMed]

32. Bonacorsi, S.; Bingen, E. Molecular Epidemiology of Escherichia coli Causing Neonatal Meningitis. Int. J. Med. Microbiol. 2005, 295, 373-381. [CrossRef]

33. Eto, D.S.; Jones, T.A.; Sundsbak, J.L.; Mulvey, M.A. Integrin-Mediated Host Cell Invasion by Type 1-Piliated Uropathogenic Escherichia coli. PLoS Pathog. 2007, 3, e100. [CrossRef]

34. Rangel, D.E.; Marín-Medina, N.; Castro, J.E.; González-Mancera, A.; Forero-Shelton, M. Observation of Bacterial Type I Pili Extension and Contraction under Fluid Flow. PLoS ONE 2013, 8, e65563. [CrossRef] [PubMed]

35. Bien, J.; Sokolova, O.; Bozko, P. Role of Uropathogenic Escherichia coli Virulence Factors in Development of Urinary Tract Infection and Kidney Damage. Int. J. Nephrol. 2012, 2012, 681473. [CrossRef]

36. Wullt, B.; Bergsten, G.; Connell, H.; Röllano, P.; Gebratsedik, N.; Hang, L.; Svanborg, C. P-Fimbriae Trigger Mucosal Responses to Escherichia coli in the Human Urinary Tract. Cell. Microbiol. 2001, 3, 255-264. [CrossRef]

37. Frömmel, U.; Lehmann, W.; Rödiger, S.; Böhm, A.; Nitschke, J.; Weinreich, J.; Groß, J.; Roggenbuck, D.; Zinke, O.; Ansorge, H.; et al. Adhesion of Human and Animal Escherichia coli Strains in Association with Their Virulence-Associated Genes and Phylogenetic Origins. Appl. Environ. Microbiol. 2013, 79, 5814-5829. [CrossRef]

38. Servin, A.L. Pathogenesis of Afa/Dr Diffusely Adhering Escherichia coli. Clin. Microbiol. Rev. 2005, 18, 264-292. [CrossRef]

39. Valle, J.; Mabbett, A.N.; Ulett, G.C.; Toledo-Arana, A.; Wecker, K.; Totsika, M.; Schembri, M.A.; Ghigo, J.-M.; Beloin, C. UpaG, a New Member of the Trimeric Autotransporter Family of Adhesins in Uropathogenic Escherichia coli. J. Bacteriol. 2008, 190, 4147-4161. [CrossRef]

40. Wallecha, A.; Oreh, H.; van der Woude, M.W.; deHaseth, P.L. Control of Gene Expression at a Bacterial Leader RNA, the Agn43 Gene Encoding Outer Membrane Protein Ag43 of Escherichia coli. J. Bacteriol. 2014, 196, 2728-2735. [CrossRef] [PubMed]

41. Cergole-Novella, M.C.; Pignatari, A.C.C.; Guth, B.E.C. Adhesion, Biofilm and Genotypic Characteristics of Antimicrobial Resistant Escherichia coli Isolates. Braz. J. Microbiol. 2015, 46, 167-171. [CrossRef]

42. Bakhtiari, N.; Gooraninezhad, S.; Karami, M. Biofilm-Producing Ability of Bovine Extraintestinal Pathogenic Escherichia coli and Its Correlation with Attachment Factors. Jundishapur J. Health Sci. 2018, 10, e77130. [CrossRef]

43. Fakruddin, M.D.; Mannan, K.S.B.; Mazumdar, R.M. Correlation Between in Vitro Biofilm Formation and Virulence Properties of Extra-Intestinal Pathogenic Escherichia coli (Expec). OnLine J. Biol. Sci. 2014, 14, 261-270. [CrossRef]

44. Wood, T.K.; González Barrios, A.F.; Herzberg, M.; Lee, J. Motility Influences Biofilm Architecture in Escherichia coli. Appl. Microbiol. Biotechnol. 2006, 72, 361-367. [CrossRef]

45. Prüß, B.M.; Besemann, C.; Denton, A.; Wolfe, A.J. A Complex Transcription Network Controls the Early Stages of Biofilm Development by Escherichia coli. J. Bacteriol. 2006, 188, 3731-3739. [CrossRef]

46. Walters, M.; Sperandio, V. Quorum Sensing in Escherichia coli and Salmonella. Int. J. Med. Microbiol. 2006, 296, 125-131. [CrossRef] [PubMed]

47. Van Houdt, R.; Michiels, C.W. Role of Bacterial Cell Surface Structures in Escherichia coli Biofilm Formation. Res. Microbiol. 2005, 156, 626-633. [CrossRef]

48. Niu, C.; Robbins, C.M.; Pittman, K.J.; Osborn, J.L.; Stubblefield, B.A.; Simmons, R.B.; Gilbert, E.S. LuxS Influences Escherichia coli Biofilm Formation through Autoinducer-2-Dependent and Autoinducer-2-Independent Modalities. FEMS Microbiol. Ecol. 2013, 83, 778-791. [CrossRef] [PubMed]

49. Zuo, J.; Yin, H.; Hu, J.; Miao, J.; Chen, Z.; Qi, K.; Wang, Z.; Gong, J.; Phouthapane, V.; Jiang, W.; et al. Lsr Operon Is Associated with AI-2 Transfer and Pathogenicity in Avian Pathogenic Escherichia coli. Vet. Res. 2019, 50, 109. [CrossRef] [PubMed]

50. Lilley, B.N.; Bassler, B.L. Regulation of Quorum Sensing in Vibrio Harveyi by LuxO and Sigma-54. Mol. Microbiol. 2000, 36, 940-954. [CrossRef] [PubMed]

51. Hou, B.; Meng, X.-R.; Zhang, L.-Y.; Tan, C.; Jin, H.; Zhou, R.; Gao, J.-F.; Wu, B.; Li, Z.-L.; Liu, M.; et al. TolC Promotes ExPEC Biofilm Formation and Curli Production in Response to Medium Osmolarity. BioMed Res. Int. 2014, 2014, e574274. [CrossRef] [PubMed]

52. Kim, K.S. Mechanisms of Microbial Traversal of the Blood-Brain Barrier. Nat. Rev. Microbiol. 2008, 6, 625-634. [CrossRef]

53. Maruvada, R.; Kim, K.S. Ibea and Ompa of Escherichia coli K1 Exploit Rac1 Activation for Invasion of Human Brain Microvascular Endothelial Cells. Infect. Immun. 2012, 80, 2035-2041. [CrossRef]

54. Brandt, S.; Shafikhani, S.; Balachandran, P.; Jin, S.; Hartig, R.; König, W.; Engel, J.; Backert, S. Use of a Novel Coinfection System Reveals a Role for Rac1, H-Ras, and CrkII Phosphorylation in Helicobacter Pylori-Induced Host Cell Actin Cytoskeletal Rearrangements. FEMS Immunol. Med. Microbiol. 2007, 50, 190-205. [CrossRef]

55. Shin, S.; Kim, K.S. RhoA and Rac1 Contribute to Type III Group B Streptococcal Invasion of Human Brain Microvascular Endothelial Cells. Biochem. Biophys. Res. Commun. 2006, 345, 538-542. [CrossRef] [PubMed] 
56. Huang, S.H.; Chen, Y.H.; Kong, G.; Chen, S.H.; Besemer, J.; Borodovsky, M.; Jong, A. A Novel Genetic Island of Meningitic Escherichia coli K1 Containing the IbeA Invasion Gene (GimA): Functional Annotation and Carbon-Source-Regulated Invasion of Human Brain Microvascular Endothelial Cells. Funct. Integr. Genom. 2001, 1, 312-322. [CrossRef] [PubMed]

57. Homeier, T.; Semmler, T.; Wieler, L.H.; Ewers, C. The GimA Locus of Extraintestinal Pathogenic E. Coli: Does Reductive Evolution Correlate with Habitat and Pathotype? PLoS ONE 2010, 5, e10877. [CrossRef] [PubMed]

58. Wang, S.; Niu, C.; Shi, Z.; Xia, Y.; Yaqoob, M.; Dai, J.; Lu, C. Effects of IbeA Deletion on Virulence and Biofilm Formation of Avian Pathogenic Escherichia coli. Infect. Immun. 2011, 79, 279-287. [CrossRef] [PubMed]

59. Cieza, R.J.; Hu, J.; Ross, B.N.; Sbrana, E.; Torres, A.G. The IbeA Invasin of Adherent-Invasive Escherichia coli Mediates Nteraction with Intestinal Epithelia and Macrophages. Infect. Immun. 2015, 83, 1904-1918. [CrossRef]

60. Germon, P.; Chen, Y.-H.; He, L.; Blanco, J.E.; Brée, A.; Schouler, C.; Huang, S.-H.; Moulin-Schouleur, M. IbeA, a Virulence Factor of Avian Pathogenic Escherichia coli. Microbiol. Read. Engl. 2005, 151, 1179-1186. [CrossRef]

61. Huang, S.H.; Wan, Z.S.; Chen, Y.H.; Jong, A.Y.; Kim, K.S. Further Characterization of Escherichia coli Brain Microvascular Endothelial Cell Invasion Gene IbeA by Deletion, Complementation, and Protein Expression. J. Infect. Dis. 2001, 183, 1071-1078. [CrossRef]

62. Huang, S.H.; Wass, C.; Fu, Q.; Prasadarao, N.V.; Stins, M.; Kim, K.S. Escherichia coli Invasion of Brain Microvascular Endothelial Cells In Vitro and In Vivo: Molecular Cloning and Characterization of Invasion Gene Ibe10. Infect. Immun. 1995, 63, 4470-4475. [CrossRef]

63. Hui, C.; Guo, Y.; Li, J.; Hao, X.; Cao, H.; Huang, S. Purification of E. coli invasin IbeA-binding protein in intestinal epithelial cells. Nan Fang Yi Ke Da Xue Xue Bao 2009, 29, 2375-2378.

64. Prasadarao, N.V.; Wass, C.A.; Huang, S.H.; Kim, K.S. Identification and Characterization of a Novel Ibe10 Binding Protein That Contributes to Escherichia coli Invasion of Brain Microvascular Endothelial Cells. Infect. Immun. 1999, 67, 1131-1138. [CrossRef] [PubMed]

65. Zou, Y.; He, L.; Huang, S.-H. Identification of a Surface Protein on Human Brain Microvascular Endothelial Cells as Vimentin Interacting with Escherichia coli Invasion Protein IbeA. Biochem. Biophys. Res. Commun. 2006, 351, 625-630. [CrossRef]

66. Zou, Y.; He, L.; Wu, C.-H.; Cao, H.; Xie, Z.-H.; Ouyang, Y.; Wang, Y.; Jong, A.; Huang, S.-H. PSF Is an IbeA-Binding Protein Contributing to Meningitic Escherichia coli K1 Invasion of Human Brain Microvascular Endothelial Cells. Med. Microbiol. Immunol. 2007, 196, 135-143. [CrossRef] [PubMed]

67. Cortes, M.A.M.; Gibon, J.; Chanteloup, N.K.; Moulin-Schouleur, M.; Gilot, P.; Germon, P. Inactivation of IbeA and IbeT Results in Decreased Expression of Type 1 Fimbriae in Extraintestinal Pathogenic Escherichia coli Strain BEN2908. Infect. Immun. 2008, 76, 4129-4136. [CrossRef]

68. Dai, J.; Wang, S.; Guerlebeck, D.; Laturnus, C.; Guenther, S.; Shi, Z.; Lu, C.; Ewers, C. Suppression Subtractive Hybridization Identifies an Autotransporter Adhesin Gene of E. Coli IMT5155 Specifically Associated with Avian Pathogenic Escherichia coli (APEC). BMC Microbiol. 2010, 10, 236. [CrossRef] [PubMed]

69. Fléchard, M.; Cortes, M.A.M.; Répérant, M.; Germon, P. New Role for the IbeA Gene in $\mathrm{H}_{2} \mathrm{O}_{2}$ Stress Resistance of Escherichia coli. J. Bacteriol. 2012, 194, 4550-4560. [CrossRef] [PubMed]

70. Su, Q.; Guan, T.; Lv, H. Siderophore Biosynthesis Coordinately Modulated the Virulence-Associated Interactive Metabolome of Uropathogenic Escherichia coli and Human Urine. Sci. Rep. 2016, 6, 24099. [CrossRef] [PubMed]

71. Simões, L.C.; Simões, M.; Vieira, M.J. Biofilm Interactions between Distinct Bacterial Genera Isolated from Drinking Water. Appl. Environ. Microbiol. 2007, 73, 6192-6200. [CrossRef]

72. Gao, Q.; Wang, X.; Xu, H.; Xu, Y.; Ling, J.; Zhang, D.; Gao, S.; Liu, X. Roles of Iron Acquisition Systems in Virulence of Extraintestinal Pathogenic Escherichia coli: Salmochelin and Aerobactin Contribute More to Virulence than Heme in a Chicken Infection Model. BMC Microbiol. 2012, 12, 143. [CrossRef]

73. Johnson, J.R. Virulence Factors in Escherichia coli Urinary Tract Infection. Clin. Microbiol. Rev. 1991, 4, 80-128. [CrossRef]

74. Crosa, J.H.; Walsh, C.T. Genetics and Assembly Line Enzymology of Siderophore Biosynthesis in Bacteria. Microbiol. Mol. Biol. Rev. 2002, 66, 223-249. [CrossRef]

75. Ratledge, C.; Dover, L.G. Iron Metabolism in Pathogenic Bacteria. Annu. Rev. Microbiol. 2000, 54, 881-941. [CrossRef] [PubMed]

76. Ozenberger, B.A.; Brickman, T.J.; McIntosh, M.A. Nucleotide Sequence of Escherichia coli Isochorismate Synthetase Gene EntC and Evolutionary Relationship of Isochorismate Synthetase and Other Chorismate-Utilizing Enzymes. J. Bacteriol. 1989, 171, 775-783. [CrossRef]

77. Liu, J.; Duncan, K.; Walsh, C.T. Nucleotide Sequence of a Cluster of Escherichia coli Enterobactin Biosynthesis Genes: Identification of EntA and Purification of Its Product 2,3-Dihydro-2,3-Dihydroxybenzoate Dehydrogenase. J. Bacteriol. 1989, 171, $791-798$. [CrossRef] [PubMed]

78. Rusnak, F.; Faraci, W.S.; Walsh, C.T. Subcloning, Expression, and Purification of the Enterobactin Biosynthetic Enzyme 2,3Dihydroxybenzoate-AMP Ligase: Demonstration of Enzyme-Bound (2,3-Dihydroxybenzoyl)Adenylate Product. Biochemistry 1989, 28, 6827-6835. [CrossRef]

79. Sakaitani, M.; Rusnak, F.; Quinn, N.R.; Tu, C.; Frigo, T.B.; Berchtold, G.A.; Walsh, C.T. Mechanistic Studies on Trans-2,3-Dihydro2,3-Dihydroxybenzoate Dehydrogenase (Ent A) in the Biosynthesis of the Iron Chelator Enterobactin. Biochemistry 1990, 29, 6789-6798. [CrossRef] [PubMed] 
80. Ehmann, D.E.; Shaw-Reid, C.A.; Losey, H.C.; Walsh, C.T. The EntF and EntE Adenylation Domains of Escherichia coli Enterobactin Synthetase: Sequestration and Selectivity in Acyl-AMP Transfers to Thiolation Domain Cosubstrates. Proc. Natl. Acad. Sci. USA 2000, 97, 2509-2514. [CrossRef]

81. Frueh, D.P.; Arthanari, H.; Koglin, A.; Vosburg, D.A.; Bennett, A.E.; Walsh, C.T.; Wagner, G. Dynamic Thiolation-Thioesterase Structure of a Non-Ribosomal Peptide Synthetase. Nature 2008, 454, 903-906. [CrossRef]

82. Gehring, A.M.; Bradley, K.A.; Walsh, C.T. Enterobactin Biosynthesis in Escherichia coli: Isochorismate Lyase (EntB) Is a Bifunctional Enzyme That Is Phosphopantetheinylated by EntD and Then Acylated by EntE Using ATP and 2,3-Dihydroxybenzoate. Biochemistry 1997, 36, 8495-8503. [CrossRef]

83. Roche, E.D.; Walsh, C.T. Dissection of the EntF Condensation Domain Boundary and Active Site Residues in Nonribosomal Peptide Synthesis. Biochemistry 2003, 42, 1334-1344. [CrossRef]

84. Rusnak, F.; Liu, J.; Quinn, N.; Berchtold, G.A.; Walsh, C.T. Subcloning of the Enterobactin Biosynthetic Gene EntB: Expression, Purification, Characterization, and Substrate Specificity of Isochorismatase. Biochemistry 1990, 29, 1425-1435. [CrossRef]

85. Gehring, A.M.; Mori, I.; Walsh, C.T. Reconstitution and Characterization of the Escherichia coli Enterobactin Synthetase from EntB, EntE, and EntF. Biochemistry 1998, 37, 2648-2659. [CrossRef]

86. Benjamin, W.H.J.; Turnbough, C.L.J.; Posey, B.S.; Briles, D.E. The Ability of Salmonella Typhimurium to Produce the Siderophore Enterobactin Is Not a Virulence Factor in Mouse Typhoid. Infect. Immun. 1985, 50, 392-397. [CrossRef]

87. Dozois, C.M.; Daigle, F.; Curtiss, R., 3rd. Identification of Pathogen-Specific and Conserved Genes Expressed in Vivo by an Avian Pathogenic Escherichia coli Strain. Proc. Natl. Acad. Sci. USA 2003, 100, 247-252. [CrossRef] [PubMed]

88. Fischbach, M.A.; Lin, H.; Zhou, L.; Yu, Y.; Abergel, R.J.; Liu, D.R.; Raymond, K.N.; Wanner, B.L.; Strong, R.K.; Walsh, C.T.; et al. The Pathogen-Associated IroA Gene Cluster Mediates Bacterial Evasion of Lipocalin 2. Proc. Natl. Acad. Sci. USA 2006, 103, 16502-16507. [CrossRef] [PubMed]

89. Garénaux, A.; Caza, M.; Dozois, C.M. The Ins and Outs of Siderophore Mediated Iron Uptake by Extra-Intestinal Pathogenic Escherichia coli. Vet. Microbiol. 2011, 153, 89-98. [CrossRef]

90. Bister, B.; Bischoff, D.; Nicholson, G.J.; Valdebenito, M.; Schneider, K.; Winkelmann, G.; Hantke, K.; Süssmuth, R.D. The Structure of Salmochelins: C-Glucosylated Enterobactins of Salmonella Enterica. Biometals 2004, 17, 471-481. [CrossRef]

91. Johnson, T.J.; Siek, K.E.; Johnson, S.J.; Nolan, L.K. DNA Sequence of a ColV Plasmid and Prevalence of Selected Plasmid-Encoded Virulence Genes among Avian Escherichia coli Strains. J. Bacteriol. 2006, 188, 745-758. [CrossRef]

92. Dobrindt, U.; Blum-Oehler, G.; Hartsch, T.; Gottschalk, G.; Ron, E.Z.; Fünfstück, R.; Hacker, J. S-Fimbria-Encoding Determinant Sfa(I) Is Located on Pathogenicity Island III(536) of Uropathogenic Escherichia coli Strain 536. Infect. Immun. 2001, 69, 4248-4256. [CrossRef]

93. Hantke, K.; Nicholson, G.; Rabsch, W.; Winkelmann, G. Salmochelins, Siderophores of Salmonella Enterica and Uropathogenic Escherichia coli Strains, Are Recognized by the Outer Membrane Receptor IroN. Proc. Natl. Acad. Sci. USA 2003, 100, 3677-3682. [CrossRef] [PubMed]

94. Lin, H.; Fischbach, M.A.; Liu, D.R.; Walsh, C.T. In Vitro Characterization of Salmochelin and Enterobactin Trilactone Hydrolases IroD, IroE, and Fes. J. Am. Chem. Soc. 2005, 127, 11075-11084. [CrossRef]

95. Caza, M.; Lépine, F.; Milot, S.; Dozois, C.M. Specific Roles of the IroBCDEN Genes in Virulence of an Avian Pathogenic Escherichia coli O78 Strain and in Production of Salmochelins. Infect. Immun. 2008, 76, 3539-3549. [CrossRef]

96. Feldmann, F.; Sorsa, L.J.; Hildinger, K.; Schubert, S. The Salmochelin Siderophore Receptor IroN Contributes to Invasion of Urothelial Cells by Extraintestinal Pathogenic Escherichia coli in Vitro. Infect. Immun. 2007, 75, 3183-3187. [CrossRef]

97. Nègre, V.L.; Bonacorsi, S.; Schubert, S.; Bidet, P.; Nassif, X.; Bingen, E. The Siderophore Receptor IroN, but Not the HighPathogenicity Island or the Hemin Receptor ChuA, Contributes to the Bacteremic Step of Escherichia coli Neonatal Meningitis. Infect. Immun. 2004, 72, 1216-1220. [CrossRef]

98. Peigne, C.; Bidet, P.; Mahjoub-Messai, F.; Plainvert, C.; Barbe, V.; Médigue, C.; Frapy, E.; Nassif, X.; Denamur, E.; Bingen, E.; et al. The Plasmid of Escherichia coli Strain S88 (O45:K1:H7) That Causes Neonatal Meningitis Is Closely Related to Avian Pathogenic E. Coli Plasmids and Is Associated with High-Level Bacteremia in a Neonatal Rat Meningitis Model. Infect. Immun. 2009, 77, 2272-2284. [CrossRef] [PubMed]

99. Russo, T.A.; McFadden, C.D.; Carlino-MacDonald, U.B.; Beanan, J.M.; Barnard, T.J.; Johnson, J.R. IroN Functions as a Siderophore Receptor and Is a Urovirulence Factor in an Extraintestinal Pathogenic Isolate of Escherichia coli. Infect. Immun. 2002, 70, 7156-7160. [CrossRef]

100. Reigstad, C.S.; Hultgren, S.J.; Gordon, J.I. Functional Genomic Studies of Uropathogenic Escherichia coli and Host Urothelial Cells When Intracellular Bacterial Communities Are Assembled. J. Biol. Chem. 2007, 282, 21259-21267. [CrossRef]

101. Carbonetti, N.H.; Williams, P.H. A Cluster of Five Genes Specifying the Aerobactin Iron Uptake System of Plasmid ColV-K30. Infect. Immun. 1984, 46, 7-12. [CrossRef] [PubMed]

102. Thariath, A.; Socha, D.; Valvano, M.A.; Viswanatha, T. Construction and Biochemical Characterization of Recombinant Cytoplasmic Forms of the IucD Protein (Lysine: N6-Hydroxylase) Encoded by the PColV-K30 Aerobactin Gene Cluster. J. Bacteriol. 1993, 175, 589-596. [CrossRef]

103. Coy, M.; Paw, B.H.; Bindereif, A.; Neilands, J.B. Isolation and Properties of N Epsilon-Hydroxylysine:Acetyl Coenzyme A N Epsilon-Transacetylase from Escherichia coli PABN11. Biochemistry 1986, 25, 2485-2489. [CrossRef] [PubMed] 
104. De Lorenzo, V.; Bindereif, A.; Paw, B.H.; Neilands, J.B. Aerobactin Biosynthesis and Transport Genes of Plasmid ColV-K30 in Escherichia coli K-12. J. Bacteriol. 1986, 165, 570-578. [CrossRef] [PubMed]

105. De Lorenzo, V.; Neilands, J.B. Characterization of IucA and IucC Genes of the Aerobactin System of Plasmid ColV-K30 in Escherichia coli. J. Bacteriol. 1986, 167, 350-355. [CrossRef]

106. Oves-Costales, D.; Kadi, N.; Challis, G.L. The Long-Overlooked Enzymology of a Nonribosomal Peptide Synthetase-Independent Pathway for Virulence-Conferring Siderophore Biosynthesis. Chem. Commun. Camb. Engl. 2009, 6530-6541. [CrossRef] [PubMed]

107. Dozois, C.M.; Fairbrother, J.M.; Harel, J.; Bossé, M. Pap-and Pil-Related DNA Sequences and Other Virulence Determinants Associated with Escherichia coli Isolated from Septicemic Chickens and Turkeys. Infect. Immun. 1992, 60, 2648-2656. [CrossRef] [PubMed]

108. Lafont, J.P.; Dho, M.; D'Hauteville, H.M.; Bree, A.; Sansonetti, P.J. Presence and Expression of Aerobactin Genes in Virulent Avian Strains of Escherichia coli. Infect. Immun. 1987, 55, 193-197. [CrossRef] [PubMed]

109. Linggood, M.A.; Roberts, M.; Ford, S.; Parry, S.H.; Williams, P.H. Incidence of the Aerobactin Iron Uptake System among Escherichia coli Isolates from Infections of Farm Animals. J. Gen. Microbiol. 1987, 133, 835-842. [CrossRef]

110. Garcia, E.C.; Brumbaugh, A.R.; Mobley, H.L.T. Redundancy and Specificity of Escherichia coli Iron Acquisition Systems during Urinary Tract Infection. Infect. Immun. 2011, 79, 1225-1235. [CrossRef]

111. Konopka, K.; Bindereif, A.; Neilands, J.B. Aerobactin-Mediated Utilization of Transferrin Iron. Biochemistry 1982, $21,6503-6508$. [CrossRef]

112. Konopka, K.; Neilands, J.B. Effect of Serum Albumin on Siderophore-Mediated Utilization of Transferrin Iron. Biochemistry 1984, 23, 2122-2127. [CrossRef]

113. Williams, P.H.; Carbonetti, N.H. Iron, Siderophores, and the Pursuit of Virulence: Independence of the Aerobactin and Enterochelin Iron Uptake Systems in Escherichia coli. Infect. Immun. 1986, 51, 942-947. [CrossRef]

114. Caza, M.; Lépine, F.; Dozois, C.M. Secretion, but Not Overall Synthesis, of Catecholate Siderophores Contributes to Virulence of Extraintestinal Pathogenic Escherichia coli. Mol. Microbiol. 2011, 80, 266-282. [CrossRef]

115. Fetherston, J.D.; Kirillina, O.; Bobrov, A.G.; Paulley, J.T.; Perry, R.D. The Yersiniabactin Transport System Is Critical for the Pathogenesis of Bubonic and Pneumonic Plague. Infect. Immun. 2010, 78, 2045-2052. [CrossRef]

116. Miller, M.C.; Fetherston, J.D.; Pickett, C.L.; Bobrov, A.G.; Weaver, R.H.; DeMoll, E.; Perry, R.D. Reduced Synthesis of the Ybt Siderophore or Production of Aberrant Ybt-like Molecules Activates Transcription of Yersiniabactin Genes in Yersinia Pestis. Microbiol. Read. Engl. 2010, 156, 2226-2238. [CrossRef] [PubMed]

117. Hancock, V.; Ferrières, L.; Klemm, P. The Ferric Yersiniabactin Uptake Receptor FyuA Is Required for Efficient Biofilm Formation by Urinary Tract Infectious Escherichia coli in Human Urine. Microbiol. Read. Engl. 2008, 154, 167-175. [CrossRef] [PubMed]

118. Paauw, A.; Leverstein-van Hall, M.A.; van Kessel, K.P.M.; Verhoef, J.; Fluit, A.C. Yersiniabactin Reduces the Respiratory Oxidative Stress Response of Innate Immune Cells. PLoS ONE 2009, 4, e8240. [CrossRef] [PubMed]

119. Elwell, L.P.; Shipley, P.L. Plasmid-Mediated Factors Associated with Virulence of Bacteria to Animals. Annu. Rev. Microbiol. 1980, 34, 465-496. [CrossRef] [PubMed]

120. Achtman, M.; Kennedy, N.; Skurray, R. Cell-Cell Interactions in Conjugating Escherichia coli: Role of TraT Protein in Surface Exclusion. Proc. Natl. Acad. Sci. USA 1977, 74, 5104-5108. [CrossRef]

121. Manning, P.A.; Beutin, L.; Achtman, M. Outer Membrane of Escherichia coli: Properties of the F Sex Factor TraT Protein Which Is Involved in Surface Exclusion. J. Bacteriol. 1980, 142, 285-294. [CrossRef]

122. Kennedy, N.; Beutin, L.; Achtman, M.; Skurray, R.; Rahmsdorf, U.; Herrlich, P. Conjugation Proteins Encoded by the F Sex Factor. Nature 1977, 270, 580-585. [CrossRef]

123. Sukupolvi, S.; O'Connor, C.D. TraT Lipoprotein, a Plasmid-Specified Mediator of Interactions between Gram-Negative Bacteria and Their Environment. Microbiol. Rev. 1990, 54, 331-341. [CrossRef]

124. Minkley, E.G.J.; Ippen-Ihler, K. Identification of a Membrane Protein Associated with Expression of the Surface Exclusion Region of the F Transfer Operon. J. Bacteriol. 1977, 129, 1613-1622. [CrossRef]

125. Minkley, E.G.J.; Willetts, N.S. Overproduction, Purification and Characterization of the F TraT Protein. Mol. Gen. Genet. 1984, 196, 225-235. [CrossRef]

126. Timmis, K.N.; Boulnois, G.J.; Bitter-Suermann, D.; Cabello, F.C. Surface Components of Escherichia coli That Mediate Resistance to the Bactericidal Activities of Serum and Phagocytes. Curr. Top. Microbiol. Immunol. 1985, 118, 197-218. [CrossRef]

127. Agüero, M.E.; Aron, L.; DeLuca, A.G.; Timmis, K.N.; Cabello, F.C. A Plasmid-Encoded Outer Membrane Protein, TraT, Enhances Resistance of Escherichia coli to Phagocytosis. Infect. Immun. 1984, 46, 740-746. [CrossRef]

128. Willetts, N.; Maule, J. Interactions between the Surface Exclusion Systems of Some F-like Plasmids. Genet. Res. 1974, 24, 81-89. [CrossRef]

129. Khalid, S.; Bond, P.J.; Carpenter, T.; Sansom, M.S.P. OmpA: Gating and Dynamics via Molecular Dynamics Simulations. Biochim. Biophys. Acta 2008, 1778, 1871-1880. [CrossRef] [PubMed]

130. Krishnan, S.; Prasadarao, N. V Outer Membrane Protein A and OprF: Versatile Roles in Gram-Negative Bacterial Infections. FEBS J. 2012, 279, 919-931. [CrossRef] [PubMed]

131. Chai, T.J.; Foulds, J. Purification of Protein A, an Outer Membrane Component Missing in Escherichia coli K-12 OmpA Mutants. Biochim. Biophys. Acta 1977, 493, 210-215. [CrossRef] 
132. Findlay, H.E.; McClafferty, H.; Ashley, R.H. Surface Expression, Single-Channel Analysis and Membrane Topology of Recombinant Chlamydia Trachomatis Major Outer Membrane Protein. BMC Microbiol. 2005, 5, 5. [CrossRef] [PubMed]

133. Reusch, R.N. Biogenesis and Functions of Model Integral Outer Membrane Proteins: Escherichia coli OmpA and Pseudomonas Aeruginosa OprF. FEBS J. 2012, 279, 893. [CrossRef]

134. Reusch, R.N. Insights into the Structure and Assembly of Escherichia coli Outer Membrane Protein A. FEBS J. 2012, $279,894-909$. [CrossRef] [PubMed]

135. Koebnik, R.; Locher, K.P.; Van Gelder, P. Structure and Function of Bacterial Outer Membrane Proteins: Barrels in a Nutshell. Mol. Microbiol. 2000, 37, 239-253. [CrossRef]

136. Ried, G.; Koebnik, R.; Hindennach, I.; Mutschler, B.; Henning, U. Membrane Topology and Assembly of the Outer Membrane Protein OmpA of Escherichia coli K12. Mol. Gen. Genet. 1994, 243, 127-135. [CrossRef]

137. Hong, H.; Szabo, G.; Tamm, L.K. Electrostatic Couplings in OmpA Ion-Channel Gating Suggest a Mechanism for Pore Opening. Nat. Chem. Biol. 2006, 2, 627-635. [CrossRef]

138. Teng, C.-H.; Xie, Y.; Shin, S.; Di Cello, F.; Paul-Satyaseela, M.; Cai, M.; Kim, K.S. Effects of OmpA Deletion on Expression of Type 1 Fimbriae in Escherichia coli K1 Strain RS218 and on the Association of E. Coli with Human Brain Microvascular Endothelial Cells. Infect. Immun. 2006, 74, 5609-5616. [CrossRef]

139. Weiser, J.N.; Gotschlich, E.C. Outer Membrane Protein A (OmpA) Contributes to Serum Resistance and Pathogenicity of Escherichia coli K-1. Infect. Immun. 1991, 59, 2252-2258. [CrossRef]

140. Meier, C.; Oelschlaeger, T.A.; Merkert, H.; Korhonen, T.K.; Hacker, J. Ability of Escherichia coli Isolates That Cause Meningitis in Newborns to Invade Epithelial and Endothelial Cells. Infect. Immun. 1996, 64, 2391-2399. [CrossRef]

141. Prasadarao, N.V.; Wass, C.A.; Weiser, J.N.; Stins, M.F.; Huang, S.H.; Kim, K.S. Outer Membrane Protein A of Escherichia coli Contributes to Invasion of Brain Microvascular Endothelial Cells. Infect. Immun. 1996, 64, 146-153. [CrossRef]

142. Wu, H.-H.; Yang, Y.-Y.; Hsieh, W.-S.; Lee, C.-H.; Leu, S.-J.C.; Chen, M.-R. OmpA Is the Critical Component for Escherichia coli Invasion-Induced Astrocyte Activation. J. Neuropathol. Exp. Neurol. 2009, 68, 677-690. [CrossRef] [PubMed]

143. Dabo, S.M.; Confer, A.; Montelongo, M.; York, P.; Wyckoff, J.H., 3rd. Vaccination with Pasteurella Multocida Recombinant OmpA Induces Strong but Non-Protective and Deleterious Th2-Type Immune Response in Mice. Vaccine 2008, 26, 4345-4351. [CrossRef] [PubMed]

144. Kim, S.W.; Choi, C.H.; Moon, D.C.; Jin, J.S.; Lee, J.H.; Shin, J.-H.; Kim, J.M.; Lee, Y.C.; Seol, S.Y.; Cho, D.T.; et al. Serum Resistance of Acinetobacter Baumannii through the Binding of Factor H to Outer Membrane Proteins. FEMS Microbiol. Lett. 2009, 301, 224-231. [CrossRef] [PubMed]

145. Prasadarao, N.V.; Blom, A.M.; Villoutreix, B.O.; Linsangan, L.C. A Novel Interaction of Outer Membrane Protein A with C4b Binding Protein Mediates Serum Resistance of Escherichia coli K1. J. Immunol. 2002, 169, 6352-6360. [CrossRef]

146. Rice, P.A.; McQuillen, D.P.; Gulati, S.; Jani, D.B.; Wetzler, L.M.; Blake, M.S.; Gotschlich, E.C. Serum Resistance of Neisseria Gonorrhoeae. Does It Thwart the Inflammatory Response and Facilitate the Transmission of Infection? Ann. N. Y. Acad. Sci. 1994, 730, 7-14. [CrossRef]

147. Sukumaran, S.K.; Selvaraj, S.K.; Prasadarao, N.V. Inhibition of Apoptosis by Escherichia coli K1 Is Accompanied by Increased Expression of BclXL and Blockade of Mitochondrial Cytochrome c Release in Macrophages. Infect. Immun. 2004, 72, 6012-6022. [CrossRef]

148. Prasadarao, N.V.; Srivastava, P.K.; Rudrabhatla, R.S.; Kim, K.S.; Huang, S.; Sukumaran, S.K. Cloning and Expression of the Escherichia coli K1 Outer Membrane Protein A Receptor, a Gp96 Homologue. Infect. Immun. 2003, 71, 1680-1688. [CrossRef]

149. Selvaraj, S.K.; Prasadarao, N. V Escherichia coli K1 Inhibits Proinflammatory Cytokine Induction in Monocytes by Preventing NF-KappaB Activation. J. Leukoc. Biol. 2005, 78, 544-554. [CrossRef]

150. Nicholson, T.F.; Watts, K.M.; Hunstad, D.A. OmpA of Uropathogenic Escherichia coli Promotes Postinvasion Pathogenesis of Cystitis. Infect. Immun. 2009, 77, 5245-5251. [CrossRef]

151. Confer, A.W.; Ayalew, S. The OmpA Family of Proteins: Roles in Bacterial Pathogenesis and Immunity. Vet. Microbiol. 2013, 163, 207-222. [CrossRef] [PubMed]

152. Fu, H.; Belaaouaj, A.A.; Dahlgren, C.; Bylund, J. Outer Membrane Protein a Deficient Escherichia coli Activates Neutrophils to Produce Superoxide and Shows Increased Susceptibility to Antibacterial Peptides. Microbes Infect. 2003, 5, 781-788. [CrossRef]

153. Wu, H.; Kuzmenko, A.; Wan, S.; Schaffer, L.; Weiss, A.; Fisher, J.H.; Kim, K.S.; McCormack, F.X. Surfactant Proteins A and D Inhibit the Growth of Gram-Negative Bacteria by Increasing Membrane Permeability. J. Clin. Investig. 2003, 111, $1589-1602$. [CrossRef] [PubMed]

154. Kröncke, K.D.; Golecki, J.R.; Jann, K. Further Electron Microscopic Studies on the Expression of Escherichia coli Group II Capsules. J. Bacteriol. 1990, 172, 3469-3472. [CrossRef] [PubMed]

155. Willis, L.M.; Whitfield, C. Structure, Biosynthesis, and Function of Bacterial Capsular Polysaccharides Synthesized by ABC Transporter-Dependent Pathways. Carbohydr. Res. 2013, 378, 35-44. [CrossRef]

156. Jorgensen, S.E.; Short, E.C.J.; Kurtz, H.J.; Mussen, H.K.; Wu, G.K. Studies on the Origin of the Alpha-Haemolysin Produced by Escherichia coli. J. Med. Microbiol. 1976, 9, 173-189. [CrossRef]

157. Bushell, S.R.; Mainprize, I.L.; Wear, M.A.; Lou, H.; Whitfield, C.; Naismith, J.H. Wzi Is an Outer Membrane Lectin That Underpins Group 1 Capsule Assembly in Escherichia coli. Structure 2013, 21, 844-853. [CrossRef] [PubMed] 
158. Orskov, F.; Orskov, I.; Jann, B.; Jann, K. Immunoelectrophoretic Patterns of Extracts from All Escherichia coli O and K Antigen Test Strains: Correlation with Pathogenicity. Acta Pathol. Microbiol. Scand. B Microbiol. Immunol. 1971, 79, 142-152. [CrossRef] [PubMed]

159. Whitfield, C. Biosynthesis and Assembly of Capsular Polysaccharides in Escherichia coli. Annu. Rev. Biochem. 2006, 75, 39-68. [CrossRef] [PubMed]

160. Kim, K.S.; Itabashi, H.; Gemski, P.; Sadoff, J.; Warren, R.L.; Cross, A.S. The K1 Capsule Is the Critical Determinant in the Development of Escherichia coli Meningitis in the Rat. J. Clin. Investig. 1992, 90, 897-905. [CrossRef]

161. Buckles, E.L.; Wang, X.; Lane, M.C.; Lockatell, C.V.; Johnson, D.E.; Rasko, D.A.; Mobley, H.L.T.; Donnenberg, M.S. Role of the K2 Capsule in Escherichia coli Urinary Tract Infection and Serum Resistance. J. Infect. Dis. 2009, 199, 1689-1697. [CrossRef]

162. Brooks, H.J.; O'Grady, F.; McSherry, M.A.; Cattell, W.R. Uropathogenic Properties of Escherichia coli in Recurrent Urinary-Tract Infection. J. Med. Microbiol. 1980, 13, 57-68. [CrossRef]

163. Opal, S.; Cross, A.; Gemski, P. K Antigen and Serum Sensitivity of Rough Escherichia coli. Infect. Immun. 1982, 37, 956-960. [CrossRef]

164. Svanborg-Edén, C.; Hagberg, L.; Hull, R.; Hull, S.; Magnusson, K.E.; Ohman, L. Bacterial Virulence versus Host Resistance in the Urinary Tracts of Mice. Infect. Immun. 1987, 55, 1224-1232. [CrossRef]

165. Leying, H.; Suerbaum, S.; Kroll, H.P.; Stahl, D.; Opferkuch, W. The Capsular Polysaccharide Is a Major Determinant of Serum Resistance in K-1-Positive Blood Culture Isolates of Escherichia coli. Infect. Immun. 1990, 58, 222-227. [CrossRef]

166. Mellata, M.; Dho-Moulin, M.; Dozois, C.M.; Curtiss, R., 3rd; Brown, P.K.; Arné, P.; Brée, A.; Desautels, C.; Fairbrother, J.M. Role of Virulence Factors in Resistance of Avian Pathogenic Escherichia coli to Serum and in Pathogenicity. Infect. Immun. 2003, 71, 536-540. [CrossRef] [PubMed]

167. Li, G.; Tivendale, K.A.; Liu, P.; Feng, Y.; Wannemuehler, Y.; Cai, W.; Mangiamele, P.; Johnson, T.J.; Constantinidou, C.; Penn, C.W.; et al. Transcriptome Analysis of Avian Pathogenic Escherichia coli O1 in Chicken Serum Reveals Adaptive Responses to Systemic Infection. Infect. Immun. 2011, 79, 1951-1960. [CrossRef] [PubMed]

168. Sáez-López, E.; Bosch, J.; Salvia, M.D.; Fernández-Orth, D.; Cepas, V.; Ferrer-Navarro, M.; Figueras-Aloy, J.; Vila, J.P.; Soto, S.M. Outbreak Caused by Escherichia coli O18: K1: H7 Sequence Type 95 in a Neonatal Intensive Care Unit in Barcelona, Spain. Pediatr. Infect. Dis. J. 2017, 36, 1079-1086. [CrossRef] [PubMed]

169. Schwan, W.R.; Beck, M.T.; Hultgren, S.J.; Pinkner, J.; Woolever, N.L.; Larson, T. Down-Regulation of the Kps Region 1 Capsular Assembly Operon Following Attachment of Escherichia coli Type 1 Fimbriae to D-Mannose Receptors. Infect. Immun. 2005, 73, 1226-1231. [CrossRef] [PubMed]

170. Horwitz, M.A.; Silverstein, S.C. Influence of the Escherichia coli Capsule on Complement Fixation and on Phagocytosis and Killing by Human Phagocytes. J. Clin. Investig. 1980, 65, 82-94. [CrossRef]

171. Stevens, P.; Huang, S.N.; Welch, W.D.; Young, L.S. Restricted Complement Activation by Escherichia coli with the K-1 Capsular Serotype: A Possible Role in Pathogenicity. J. Immunol. 1978, 121, 2174-2180.

172. Howard, C.J.; Glynn, A.A. The Virulence for Mice of Strains of Escherichia coli Related to the Effects of K Antigens on Their Resistance to Phagocytosis and Killing by Complement. Immunology 1971, 20, 767-777. [PubMed]

173. Nicholson, A.M.; Glynn, A.A. Investigation of the Effect of K Antigen in Escherichia coli Urinary Tract Infections by Use of a Mouse Model. Br. J. Exp. Pathol. 1975, 56, 549-553.

174. Jennings, H.J.; Lugowski, C. Immunochemistry of Groups A, B, and C Meningococcal Polysaccharide-Tetanus Toxoid Conjugates. J. Immunol. 1981, 127, 1011-1018.

175. Comstock, L.E.; Kasper, D.L. Bacterial Glycans: Key Mediators of Diverse Host Immune Responses. Cell 2006, 126, 847-850. [CrossRef]

176. Spinosa, M.R.; Progida, C.; Talà, A.; Cogli, L.; Alifano, P.; Bucci, C. The Neisseria Meningitidis Capsule Is Important for Intracellular Survival in Human Cells. Infect. Immun. 2007, 75, 3594-3603. [CrossRef] [PubMed]

177. Williams, A.E.; Maskell, D.J.; Moxon, E.R. Relationship between Intracellular Survival in Macrophages and Virulence of Haemophilus Influenzae Type b. J. Infect. Dis. 1991, 163, 1366-1369. [CrossRef] [PubMed]

178. Kim, K.J.; Elliott, S.J.; Di Cello, F.; Stins, M.F.; Kim, K.S. The K1 Capsule Modulates Trafficking of E. Coli-Containing Vacuoles and Enhances Intracellular Bacterial Survival in Human Brain Microvascular Endothelial Cells. Cell. Microbiol. 2003, 5, $245-252$. [CrossRef]

179. Nikulin, J.; Panzner, U.; Frosch, M.; Schubert-Unkmeir, A. Intracellular Survival and Replication of Neisseria Meningitidis in Human Brain Microvascular Endothelial Cells. Int. J. Med. Microbiol. 2006, 296, 553-558. [CrossRef] [PubMed]

180. Agüero, M.E.; Cabello, F.C. Relative Contribution of ColV Plasmid and K1 Antigen to the Pathogenicity of Escherichia coli. Infect. Immun. 1983, 40, 359-368. [CrossRef] [PubMed]

181. Van Dijk, W.C.; Verbrugh, H.A.; van der Tol, M.E.; Peters, R.; Verhoef, J. Role of Escherichia coli K Capsular Antigens during Complement Activation, C3 Fixation, and Opsonization. Infect. Immun. 1979, 25, 603-609. [CrossRef]

182. Orskov, I.; Orskov, F. Escherichia coli in Extra-Intestinal Infections. J. Hyg. 1985, 95, 551-575. [CrossRef] [PubMed]

183. Verweij-van Vught, A.M.; van den Bosch, J.F.; Namavar, F.; Sparrius, M.; MacLaren, D.M. K Antigens of Escherichia coli and Virulence in Urinary-Tract Infection: Studies in a Mouse Model. J. Med. Microbiol. 1983, 16, 147-155. [CrossRef]

184. Baldy-Chudzik, K.; Bok, E.; Mazurek, J. Well-known and new variants of pathogenic Escherichia coli as a consequence of the plastic genome. Postepy Hig. Med. Dosw. 2015, 69, 345-361. [CrossRef] 
185. Johnson, J.R.; Russo, T.A. Extraintestinal Pathogenic Escherichia coli: “The Other Bad E. Coli”. J. Lab. Clin. Med. 2002, 139, 155-162. [CrossRef] [PubMed]

186. Ombarak, R.A.; Hinenoya, A.; Awasthi, S.P.; Iguchi, A.; Shima, A.; Elbagory, A.-R.M.; Yamasaki, S. Prevalence and Pathogenic Potential of Escherichia coli Isolates from Raw Milk and Raw Milk Cheese in Egypt. Int. J. Food Microbiol. 2016, $221,69-76$. [CrossRef] [PubMed]

187. Mitchell, N.M.; Johnson, J.R.; Johnston, B.; Curtiss, R., 3rd; Mellata, M. Zoonotic Potential of Escherichia coli Isolates from Retail Chicken Meat Products and Eggs. Appl. Environ. Microbiol. 2015, 81, 1177-1187. [CrossRef]

188. Grande Burgos, M.J.; Fernández Márquez, M.L.; Pérez Pulido, R.; Gálvez, A.; Lucas López, R. Virulence Factors and Antimicrobial Resistance in Escherichia coli Strains Isolated from Hen Egg Shells. Int. J. Food Microbiol. 2016, 238, 89-95. [CrossRef] [PubMed]

189. Mora, A.; Viso, S.; López, C.; Alonso, M.P.; García-Garrote, F.; Dabhi, G.; Mamani, R.; Herrera, A.; Marzoa, J.; Blanco, M.; et al. Poultry as Reservoir for Extraintestinal Pathogenic Escherichia coli O45:K1:H7-B2-ST95 in Humans. Vet. Microbiol. 2013, 167, 506-512. [CrossRef] [PubMed]

190. Vila, J.; Sáez-López, E.; Johnson, J.R.; Römling, U.; Dobrindt, U.; Cantón, R.; Giske, C.G.; Naas, T.; Carattoli, A.; Martínez-Medina, M.; et al. Escherichia coli: An Old Friend with New Tidings. FEMS Microbiol. Rev. 2016, 40, 437-463. [CrossRef]

191. Felmlee, T.; Pellett, S.; Welch, R.A. Nucleotide Sequence of an Escherichia coli Chromosomal Hemolysin. J. Bacteriol. 1985, 163, 94-105. [CrossRef]

192. Wandersman, C.; Delepelaire, P. TolC, an Escherichia coli Outer Membrane Protein Required for Hemolysin Secretion. Proc. Natl. Acad. Sci. USA 1990, 87, 4776-4780. [CrossRef]

193. Welch, R.A. Pore-Forming Cytolysins of Gram-Negative Bacteria. Mol. Microbiol. 1991, 5, 521-528. [CrossRef]

194. Shanthalingam, S.; Srikumaran, S. Intact Signal Peptide of CD18, the Beta-Subunit of Beta2-Integrins, Renders Ruminants Susceptible to Mannheimia Haemolytica Leukotoxin. Proc. Natl. Acad. Sci. USA 2009, 106, 15448-15453. [CrossRef]

195. Morova, J.; Osicka, R.; Masin, J.; Sebo, P. RTX Cytotoxins Recognize Beta2 Integrin Receptors through N-Linked Oligosaccharides. Proc. Natl. Acad. Sci. USA 2008, 105, 5355-5360. [CrossRef]

196. Lally, E.T.; Kieba, I.R.; Sato, A.; Green, C.L.; Rosenbloom, J.; Korostoff, J.; Wang, J.F.; Shenker, B.J.; Ortlepp, S.; Robinson, M.K.; et al. RTX Toxins Recognize a Beta2 Integrin on the Surface of Human Target Cells. J. Biol. Chem. 1997, 272, 30463-30469. [CrossRef]

197. Skals, M.; Jensen, U.B.; Ousingsawat, J.; Kunzelmann, K.; Leipziger, J.; Praetorius, H.A. Escherichia coli Alpha-Hemolysin Triggers Shrinkage of Erythrocytes via K(Ca)3.1 and TMEM16A Channels with Subsequent Phosphatidylserine Exposure. J. Biol. Chem. 2010, 285, 15557-15565. [CrossRef]

198. Jorgensen, S.E.; Mulcahy, P.F.; Wu, G.K.; Louis, C.F. Calcium Accumulation in Human and Sheep Erythrocytes That Is Induced by Escherichia coli Hemolysin. Toxicon 1983, 21, 717-727. [CrossRef]

199. Grimminger, F.; Scholz, C.; Bhakdi, S.; Seeger, W. Subhemolytic Doses of Escherichia coli Hemolysin Evoke Large Quantities of Lipoxygenase Products in Human Neutrophils. J. Biol. Chem. 1991, 266, 14262-14269. [CrossRef]

200. Valeva, A.; Walev, I.; Kemmer, H.; Weis, S.; Siegel, I.; Boukhallouk, F.; Wassenaar, T.M.; Chavakis, T.; Bhakdi, S. Binding of Escherichia coli Hemolysin and Activation of the Target Cells Is Not Receptor-Dependent. J. Biol. Chem. 2005, 280, 36657-36663. [CrossRef] [PubMed]

201. Grimminger, F.; Rose, F.; Sibelius, U.; Meinhardt, M.; Pötzsch, B.; Spriestersbach, R.; Bhakdi, S.; Suttorp, N.; Seeger, W. Human Endothelial Cell Activation and Mediator Release in Response to the Bacterial Exotoxins Escherichia coli Hemolysin and Staphylococcal Alpha-Toxin. J. Immunol. 1997, 159, 1909-1916.

202. Caprioli, A.; Falbo, V.; Roda, L.G.; Ruggeri, F.M.; Zona, C. Partial Purification and Characterization of an Escherichia coli Toxic Factor That Induces Morphological Cell Alterations. Infect. Immun. 1983, 39, 1300-1306. [CrossRef]

203. Flatau, G.; Lemichez, E.; Gauthier, M.; Chardin, P.; Paris, S.; Fiorentini, C.; Boquet, P. Toxin-Induced Activation of the G Protein P21 Rho by Deamidation of Glutamine. Nature 1997, 387, 729-733. [CrossRef] [PubMed]

204. Schmidt, G.; Sehr, P.; Wilm, M.; Selzer, J.; Mann, M.; Aktories, K. Gln 63 of Rho Is Deamidated by Escherichia coli Cytotoxic Necrotizing Factor-1. Nature 1997, 387, 725-729. [CrossRef]

205. Lemichez, E.; Flatau, G.; Bruzzone, M.; Boquet, P.; Gauthier, M. Molecular Localization of the Escherichia coli Cytotoxic Necrotizing Factor CNF1 Cell-Binding and Catalytic Domains. Mol. Microbiol. 1997, 24, 1061-1070. [CrossRef]

206. Knust, Z.; Blumenthal, B.; Aktories, K.; Schmidt, G. Cleavage of Escherichia coli Cytotoxic Necrotizing Factor 1 Is Required for Full Biologic Activity. Infect. Immun. 2009, 77, 1835-1841. [CrossRef]

207. Kim, K.J.; Chung, J.W.; Kim, K.S. 67 KDa Laminin Receptor Promotes Internalization of Cytotoxic Necrotizing Factor 1-Expressing Escherichia coli K1 into Human Brain Microvascular Endothelial Cells. J. Biol. Chem. 2005, 280, 1360-1368. [CrossRef]

208. McNichol, B.A.; Rasmussen, S.B.; Carvalho, H.M.; Meysick, K.C.; O’Brien, A.D. Two Domains of Cytotoxic Necrotizing Factor Type 1 Bind the Cellular Receptor, Laminin Receptor Precursor Protein. Infect. Immun. 2007, 75, 5095-5104. [CrossRef]

209. Pei, S.; Doye, A.; Boquet, P. Mutation of Specific Acidic Residues of the CNF1 T Domain into Lysine Alters Cell Membrane Translocation of the Toxin. Mol. Microbiol. 2001, 41, 1237-1247. [CrossRef]

210. Munro, P.; Flatau, G.; Doye, A.; Boyer, L.; Oregioni, O.; Mege, J.-L.; Landraud, L.; Lemichez, E. Activation and Proteasomal Degradation of Rho GTPases by Cytotoxic Necrotizing Factor-1 Elicit a Controlled Inflammatory Response. J. Biol. Chem. 2004, 279, 35849-35857. [CrossRef] [PubMed]

211. Andreu, A.; Stapleton, A.E.; Fennell, C.; Lockman, H.A.; Xercavins, M.; Fernandez, F.; Stamm, W.E. Urovirulence Determinants in Escherichia coli Strains Causing Prostatitis. J. Infect. Dis. 1997, 176, 464-469. [CrossRef] 
212. Welch, R.A. Uropathogenic Escherichia coli-Associated Exotoxins. Microbiol. Spectr. 2016, 1-10. [CrossRef] [PubMed]

213. Maroncle, N.M.; Sivick, K.E.; Brady, R.; Stokes, F.-E.; Mobley, H.L.T. Protease Activity, Secretion, Cell Entry, Cytotoxicity, and Cellular Targets of Secreted Autotransporter Toxin of Uropathogenic Escherichia coli. Infect. Immun. 2006, 74, 6124-6134. [CrossRef] [PubMed]

214. Guyer, D.M.; Radulovic, S.; Jones, F.-E.; Mobley, H.L.T. Sat, the Secreted Autotransporter Toxin of Uropathogenic Escherichia coli, Is a Vacuolating Cytotoxin for Bladder and Kidney Epithelial Cells. Infect. Immun. 2002, 70, 4539-4546. [CrossRef]

215. Liévin-Le Moal, V.; Comenge, Y.; Ruby, V.; Amsellem, R.; Nicolas, V.; Servin, A.L. Secreted Autotransporter Toxin (Sat) Triggers Autophagy in Epithelial Cells That Relies on Cell Detachment. Cell. Microbiol. 2011, 13, 992-1013. [CrossRef]

216. Henderson, I.R.; Czeczulin, J.; Eslava, C.; Noriega, F.; Nataro, J.P. Characterization of Pic, a Secreted Protease of Shigella Flexneri and Enteroaggregative Escherichia coli. Infect. Immun. 1999, 67, 5587-5596. [CrossRef]

217. Parreira, V.R.; Gyles, C.L. A Novel Pathogenicity Island Integrated Adjacent to the ThrW TRNA Gene of Avian Pathogenic Escherichia coli Encodes a Vacuolating Autotransporter Toxin. Infect. Immun. 2003, 71, 5087-5096. [CrossRef]

218. Ruiz-Perez, F.; Wahid, R.; Faherty, C.S.; Kolappaswamy, K.; Rodriguez, L.; Santiago, A.; Murphy, E.; Cross, A.; Sztein, M.B.; Nataro, J.P. Serine Protease Autotransporters from Shigella Flexneri and Pathogenic Escherichia coli Target a Broad Range of Leukocyte Glycoproteins. Proc. Natl. Acad. Sci. USA 2011, 108, 12881-12886. [CrossRef] [PubMed]

219. Parham, N.J.; Pollard, S.J.; Desvaux, M.; Scott-Tucker, A.; Liu, C.; Fivian, A.; Henderson, I.R. Distribution of the Serine Protease Autotransporters of the Enterobacteriaceae among Extraintestinal Clinical Isolates of Escherichia coli. J. Clin. Microbiol. 2005, 43, 4076-4082. [CrossRef] [PubMed]

220. Tzouvelekis, L.S.; Markogiannakis, A.; Piperaki, E.; Souli, M.; Daikos, G.L. Treating Infections Caused by CarbapenemaseProducing Enterobacteriaceae. Clin. Microbiol. Infect. 2014, 20, 862-872. [CrossRef] [PubMed]

221. Nordmann, P.; Naas, T.; Poirel, L. Global Spread of Carbapenemase-Producing Enterobacteriaceae. Emerg. Infect. Dis. 2011, 17, 1791-1798. [CrossRef]

222. World Health Organization. Antimicrobial Resistance Global Report on Surveillance. 2014. Available online: http:/ /www.who. int/drugresistance/documents/surveillancereport/en/ (accessed on 17 December 2020).

223. Cantón, R.; Coque, T.M. The CTX-M Beta-Lactamase Pandemic. Curr. Opin. Microbiol. 2006, 9, 466-475. [CrossRef] [PubMed]

224. Rodríguez-Martínez, J.M.; Cano, M.E.; Velasco, C.; Martínez-Martínez, L.; Pascual, A. Plasmid-Mediated Quinolone Resistance: An Update. J. Infect. Chemother. 2011, 17, 149-182. [CrossRef]

225. D'Andrea, M.M.; Arena, F.; Pallecchi, L.; Rossolini, G.M. CTX-M-Type $\beta$-Lactamases: A Successful Story of Antibiotic Resistance. Int. J. Med. Microbiol. 2013, 303, 305-317. [CrossRef]

226. Lautenbach, E.; Patel, J.B.; Bilker, W.B.; Edelstein, P.H.; Fishman, N.O. Extended-Spectrum Beta-Lactamase-Producing Escherichia coli and Klebsiella Pneumoniae: Risk Factors for Infection and Impact of Resistance on Outcomes. Clin. Infect. Dis. 2001, 32, 1162-1171. [CrossRef] [PubMed]

227. Tumbarello, M.; Sanguinetti, M.; Montuori, E.; Trecarichi, E.M.; Posteraro, B.; Fiori, B.; Citton, R.; D'Inzeo, T.; Fadda, G.; Cauda, R.; et al. Predictors of Mortality in Patients with Bloodstream Infections Caused by Extended-Spectrum-Beta-Lactamase-Producing Enterobacteriaceae: Importance of Inadequate Initial Antimicrobial Treatment. Antimicrob. Agents Chemother. 2007, 51, 1987-1994. [CrossRef]

228. Foxman, B. The Epidemiology of Urinary Tract Infection. Nat. Rev. Urol. 2010, 7, 653-660. [CrossRef] [PubMed]

229. Pérez-Etayo, L.; González, D.; Vitas, A.I. The Aquatic Ecosystem, a Good Environment for the Horizontal Transfer of Antimicrobial Resistance and Virulence-Associated Factors Among Extended Spectrum $\beta$-Lactamases Producing E. Coli. Microorganisms 2020, 8, 568. [CrossRef]

230. Livermore, D.M.; Woodford, N. The Beta-Lactamase Threat in Enterobacteriaceae, Pseudomonas and Acinetobacter. Trends Microbiol. 2006, 14, 413-420. [CrossRef]

231. Paterson, D.L.; Bonomo, R.A. Extended-Spectrum Beta-Lactamases: A Clinical Update. Clin. Microbiol. Rev. 2005, 18, 657-686. [CrossRef]

232. Pitout, J.D.D.; Laupland, K.B. Extended-Spectrum Beta-Lactamase-Producing Enterobacteriaceae: An Emerging Public-Health Concern. Lancet Infect. Dis. 2008, 8, 159-166. [CrossRef]

233. Rodríguez-Baño, J.; Pascual, A. Clinical Significance of Extended-Spectrum Beta-Lactamases. Expert Rev. Anti-Infect. Ther. 2008, 6, 671-683. [CrossRef]

234. Olsson, O.; Bergström, S.; Normark, S. Identification of a Novel AmpC Beta-Lactamase Promoter in a Clinical Isolate of Escherichia coli. EMBO J. 1982, 1, 1411-1416. [CrossRef]

235. Doi, Y.; Paterson, D.L. Detection of Plasmid-Mediated Class C Beta-Lactamases. Int. J. Infect. Dis. 2007, 11, 191-197. [CrossRef] [PubMed]

236. Philippon, A.; Arlet, G.; Jacoby, G.A. Plasmid-Determined AmpC-Type Beta-Lactamases. Antimicrob. Agents Chemother. 2002, 46, 1-11. [CrossRef] [PubMed]

237. Yong, D.; Toleman, M.A.; Giske, C.G.; Cho, H.S.; Sundman, K.; Lee, K.; Walsh, T.R. Characterization of a New Metallo-BetaLactamase Gene, Bla(NDM-1), and a Novel Erythromycin Esterase Gene Carried on a Unique Genetic Structure in Klebsiella Pneumoniae Sequence Type 14 from India. Antimicrob. Agents Chemother. 2009, 53, 5046-5054. [CrossRef] 
238. Castanheira, M.; Deshpande, L.M.; Mathai, D.; Bell, J.M.; Jones, R.N.; Mendes, R.E. Early Dissemination of NDM-1- and OXA-181Producing Enterobacteriaceae in Indian Hospitals: Report from the SENTRY Antimicrobial Surveillance Program, 2006-2007. Antimicrob. Agents Chemother. 2011, 55, 1274-1278. [CrossRef] [PubMed]

239. Nordmann, P.; Poirel, L.; Walsh, T.R.; Livermore, D.M. The Emerging NDM Carbapenemases. Trends Microbiol. 2011, 19, 588-595. [CrossRef] [PubMed]

240. Peirano, G.; Schreckenberger, P.C.; Pitout, J.D.D. Characteristics of NDM-1-Producing Escherichia coli Isolates That Belong to the Successful and Virulent Clone ST131. Antimicrob. Agents Chemother. 2011, 55, 2986-2988. [CrossRef] [PubMed]

241. Mantengoli, E.; Luzzaro, F.; Pecile, P.; Cecconi, D.; Cavallo, A.; Attala, L.; Bartoloni, A.; Rossolini, G.M. Escherichia coli ST131 Producing Extended-Spectrum $\beta$-Lactamases plus VIM-1 Carbapenemase: Further Narrowing of Treatment Options. Clin. Infect. Dis. Off. Publ. Infect. Dis. Soc. Am. 2011, 52, 690-691. [CrossRef] [PubMed]

242. Morris, D.; Boyle, F.; Ludden, C.; Condon, I.; Hale, J.; O'Connell, N.; Power, L.; Boo, T.W.; Dhanji, H.; Lavallee, C.; et al. Production of KPC-2 Carbapenemase by an Escherichia coli Clinical Isolate Belonging to the International ST131 Clone. Antimicrob. Agents Chemother. 2011, 55, 4935-4936. [CrossRef]

243. Stone, N.R.H.; Woodford, N.; Livermore, D.M.; Howard, J.; Pike, R.; Mushtaq, S.; Perry, C.; Hopkins, S. Breakthrough Bacteraemia Due to Tigecycline-Resistant Escherichia coli with New Delhi Metallo- $\beta$-Lactamase (NDM)-1 Successfully Treated with Colistin in a Patient with Calciphylaxis. J. Antimicrob. Chemother. 2011, 66, 2677-2678. [CrossRef] 